\title{
The emphasis on Supervised Agricultural Experience programs by high school agricultural education teachers
}

\author{
John A. Workman \\ West Virginia University
}

Follow this and additional works at: https://researchrepository.wvu.edu/etd

\section{Recommended Citation}

Workman, John A., "The emphasis on Supervised Agricultural Experience programs by high school agricultural education teachers" (2010). Graduate Theses, Dissertations, and Problem Reports. 3003. https://researchrepository.wvu.edu/etd/3003

This Thesis is protected by copyright and/or related rights. It has been brought to you by the The Research Repository @ WVU with permission from the rights-holder(s). You are free to use this Thesis in any way that is permitted by the copyright and related rights legislation that applies to your use. For other uses you must obtain permission from the rights-holder(s) directly, unless additional rights are indicated by a Creative Commons license in the record and/ or on the work itself. This Thesis has been accepted for inclusion in WVU Graduate Theses, Dissertations, and Problem Reports collection by an authorized administrator of The Research Repository @ WVU. For more information, please contact researchrepository@mail.wvu.edu. 
The Emphasis on Supervised Agricultural Experience Programs by High School Agricultural Education Teachers

John A. Workman

Thesis submitted to the

Davis College of Agriculture, Natural Resources and Design

at West Virginia University

in partial fulfillment of the requirements

for the degree of

\section{Master of Science}

in

Agricultural and Extension Education

Harry N. Boone Jr., Ph.D., Chair

Deborah A. Boone, Ph.D.

Douglas D. LaVergne, Ph.D.

Division of Resource Management

Morgantown, West Virginia

2010

Keywords: Agricultural Education, Supervised Agricultural Experience Programs 


\section{ABSTRACT \\ The Emphasis on Supervised Agricultural Experience Programs by High School Agricultural Education Teachers.}

\section{John Ashley Workman}

Every year thousands of high school FFA members around the nation earn degrees through their SAE programs. Supervised Agriculture Experience programs (SAEs) are used for students to take interest, mix with information and practices learned in the classroom and apply them in a real life scenario. The purpose of this study was to look at the emphasis and importance agricultural teachers are putting on SAEs in their programs. The study was limited to six states, approximately 1,500 teachers. The final set of useable surveys numbered 391 (26.1\%). Educators were presented with an online survey, which was broken down into sections. Many of the findings pointed to issues with time, numbers, and other activities in agricultural education as reasons trends show a decline in the number of students with SAEs. 


\section{DEDICATION}

I would like to dedicate this thesis to All of those individuals in my past Who pushed me to do more, and

To those who took the time to teach

Me the importance of Agriculture. 


\section{ACKNOWLEDGEMENTS}

Vince Lombardi once said that "The price of success is hard work, dedication to the job at hand, and the determination that whether we win or lose, we have applied the best of ourselves to the task at hand." This thesis that I have been working on for the past year plus of my life has not been an easy task. Through hard work, dedication and determination I was able to apply myself to accomplish this task. However, without a group of very important people in my life this task would not have been accomplished.

I would like to take the time to thank the Agricultural and Extension Education advisors at West Virginia University, Dr. Harry Boone, Dr. Debby Boone, and Dr. Douglas LaVergne. Because of all of your dedication to your job and the field of agriculture you make the Agricultural and Extension Education a wonderful program. I appreciate all the time you have given to me to help me lay out my "plan" and make earning this master's degree possible. I believe that you are often looked over and probably feel you are unappreciated. I promise you that you are more appreciated by your students than you know. You have made my experience at WVU very enjoyable and educational and I thank you for that.

I want to extend a sincere thank you to my friends here at West Virginia University. You often hear that you will meet some of the greatest friends of your life when you go to college, I did. It seems like yesterday I walked on to this campus knowing very few people, I leave here with a group of lifelong friends. We came to Morgantown as individuals from many different areas and backgrounds, but we leave here as friends and are all the better for it. 
To my family I cannot say enough. Each of you has played a huge role in my life and has a great impact in making me the man I am today. To my Grandfather and Dad, I thank you for instilling the value of hard work, tough love, and agriculture to me. Many times I did not understand why you were often so tough on me and required so much of me. Looking back I thank you for that because it has made all the difference in me. To my Grandmothers, I have been so blessed to have you both in my life for so long. You have instilled many great values in me. To my mother and sisters, you all have always been the back bone to our family. When I was away I knew home was only a phone call away with any of you. You always reminded me of home and how everything has a time and purpose and it in time we would see that.

Sometimes it does not take much to have an impact on someone's life. We never know what the simplest nice comment or gesture may mean to someone. All of you have played a huge role in my life at one point or another and I know that you will continue to do so. We were all brought together for a reason; you will never fully know how much you all have meant to me. 


\section{TABLE OF CONTENTS}

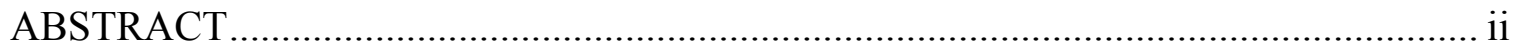

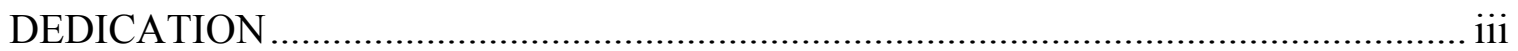

ACKNOWLEDGEMENTS ................................................................................ iv

TABLE OF CONTENTS................................................................................... vi

LIST OF TABLES .............................................................................................. vii

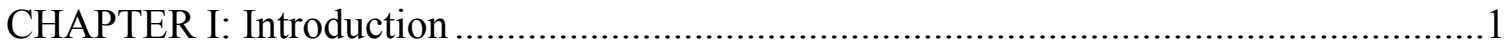

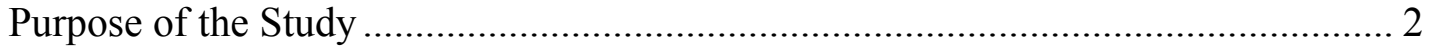

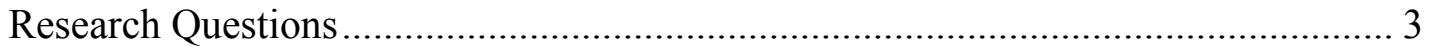

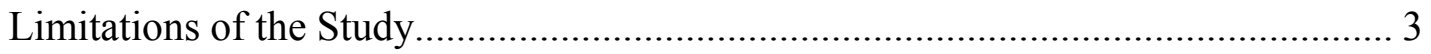

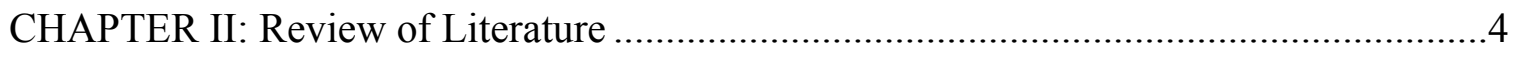

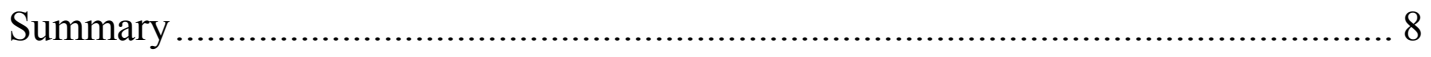

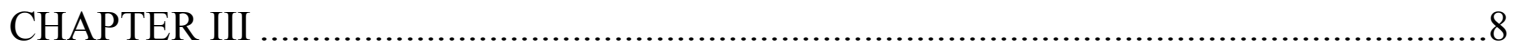

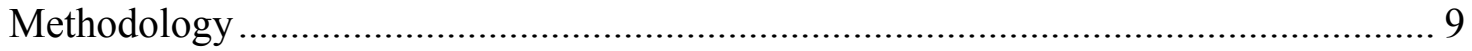

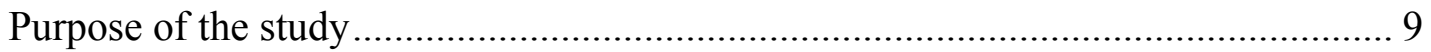

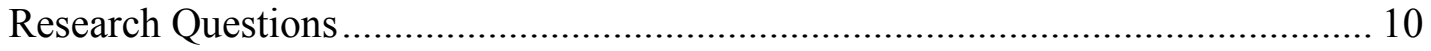

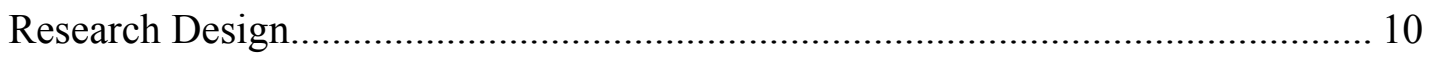

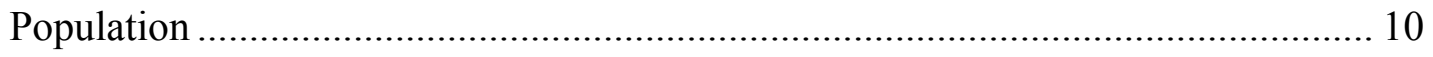

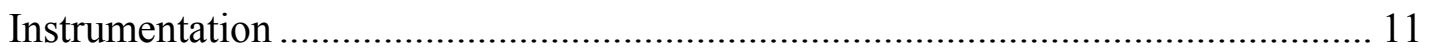

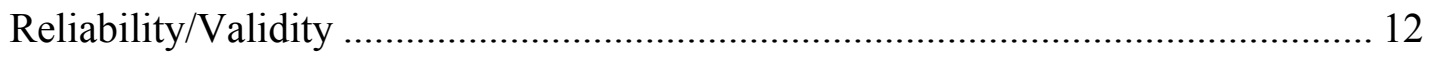

Data Collection Procedures............................................................................... 12

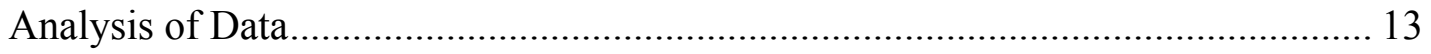

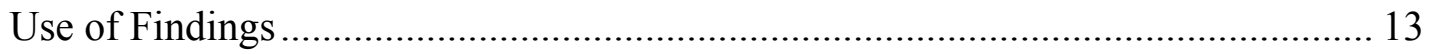

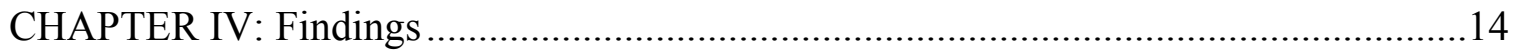

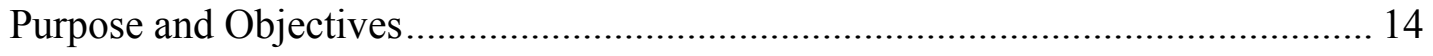




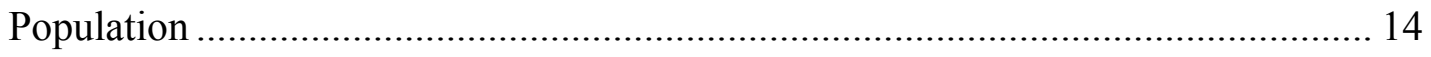

Demographic Characteristics of Respondents ........................................................ 15

Statements Concerning the Values of SAEs ............................................................ 20

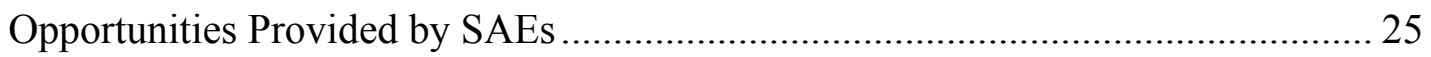

Time Issues Associated with SAEs....................................................................... 28

Teachers Thoughts and Opinions on SAEs ......................................................... 34

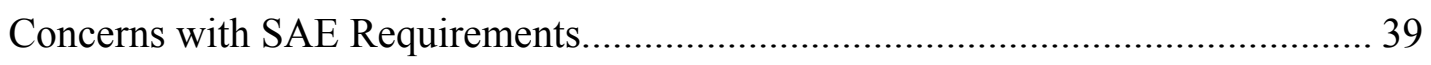

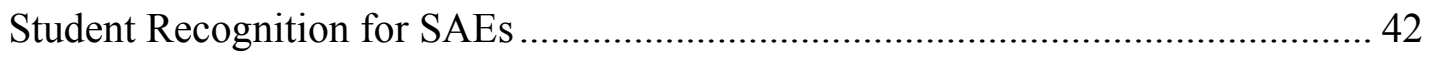

Teacher Competence with SAEs ..................................................................... 48

Support Issues Associated with SAEs ............................................................. 52

Program Issues Associated with SAEs ………………………………………..... 57

Program Statistics for Agricultural Education Programs.......................................... 60

Numbers for Agricultural Education Program......................................................... 63

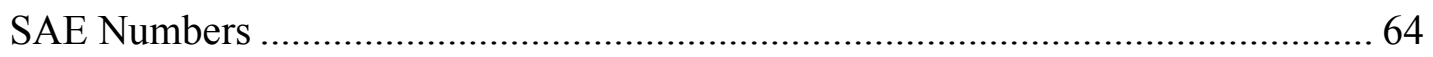

CHAPTER V: Summary, Conclusions, and Recommendations ……………………......67

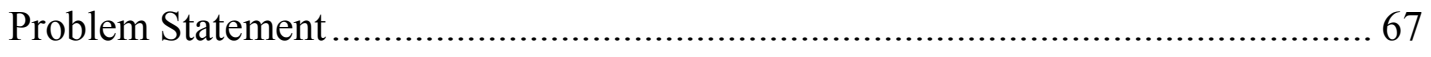

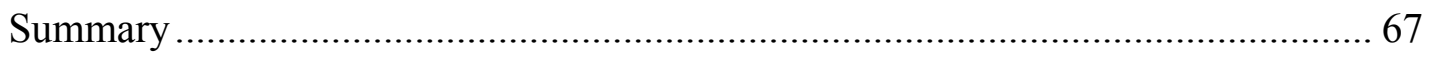

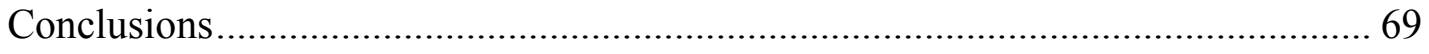

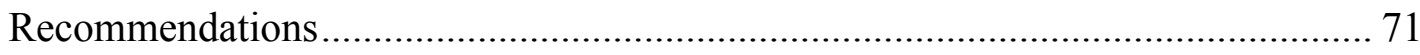

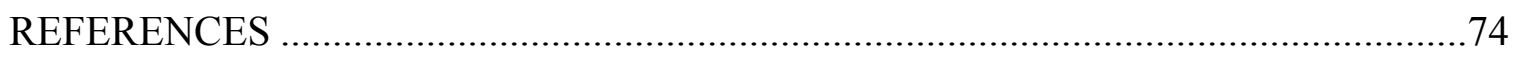

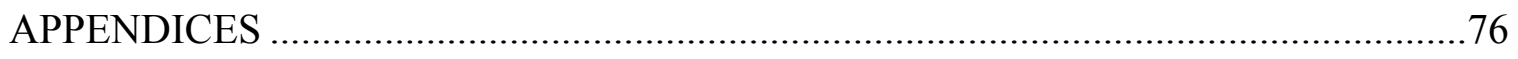

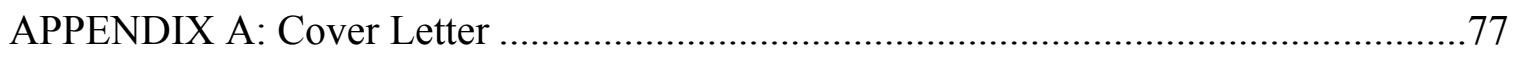

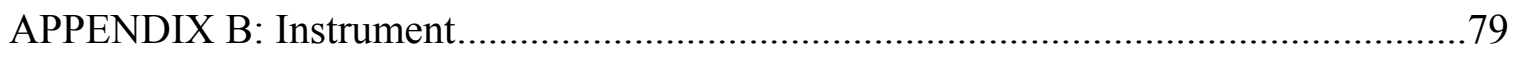

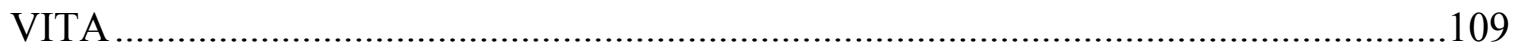




\section{LIST OF TABLES}

Table Title

$1 \quad$ Number of Agricultural Education Teachers Who Responded to Survey...........15

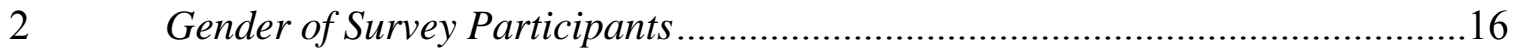

3 Age of Agricultural Education Teachers .....................................................17

$4 \quad$ Years of Agricultural Education Teaching Experience Reported by Research Participants ....................................................................................... 18

$5 \quad$ Area Agricultural Education Teachers Grew Up .........................................19

6 Type of School District Served by the Agricultural Education Teachers ...........20

7 Responses to Selected Statements Concerning the Value of SAEs .....................23

8 Composite Score Averages for Selected Statements on the Value of SAEs ........25

9 Responses to Selected Statements Concerning Opportunities Provided by SAEs

10 Composite Score Averages for Selected Statements on Opportunities Provided by SAEs.

11 Responses to Selected Statements Concerning Time Issues Associated with SAEs

12 Composite Score Averages for Selected Statements on Time Issues Associated with SAEs.

13 Responses to Selected Statements Concerning Teachers' Thoughts/Opinions on SAEs.....

14 Composite Score Averages for Selected Statements on Teachers' Thoughts/Opinions Associated with SAEs .....

15 Responses to Selected Statements Concerning SAE Requirements

16 Composite Score Averages for Selected Statements on SAE Requirements.

17 Responses to Selected Statements Concerning Student Recognition for SAEs

18 Composite Score Averages for Selected Statements on student Recognition Issues with SAEs.... 
19 Responses to Selected Statements Concerning Teacher Competence with SAEs.

20 Composite Score Averages for Selected Statements on Teacher Competence with SAEs

21 Responses to Selected Statements Concerning Support Issues Associated with SAEs

22 Composite Score Averages for Selected Statements Associated with Support of SAEs

23 Responses to Selected Statements Concerning Program Issues Associated with SAEs.

24 Composite Score Averages for Selected Statements on Program Issues Associated with SAEs.

25 Self-Reported Program Statistics for Agricultural Education Programs............62

26 Self-Reported SAE Percentages for Agricultural Education Programs ..............64

27 Self-Reported SAE Numbers for Agricultural Education Programs ..................66 


\section{CHAPTER I}

\section{Introduction}

Supervised agricultural experience programs (SAE) are one of the three main components of an agricultural education program (National FFA Organization, n. d.) The three components of agricultural education; classroom instruction, SAE, and FFA; work together to provide members with leadership, academic, and career experiences that lead to future success (National FFA Organization, n. d.). The SAE portion of agricultural education is a great example of one line of the FFA motto of the FFA organization, Learning by Doing (National FFA Organization, 2009).

Supervised agricultural experience programs are a way for students to take their personal interest, mix in what they have learned in the classroom and laboratory, and learn in a "real life" scenario. SAE's can range from a student raising beef cattle to mowing lawns, from a small garden to working with a veterinarian. SAE programs help students apply information learned in the classroom in real settings. Phipps, Osborne, Dyer and Ball (2008) explained that "SAE programs can fill a significant void in the application and transfer of acquired knowledge and skills, and often aid in developing positive attitudes toward learning. In short, SAE programs bridge the gap between theory and experience" (p.445).

For a SAE to be successful it requires a lot of time and support. It is crucial to any SAE that both student and teacher see it as a valuable learning experience and that both are willing to put the work into the SAE program. If this occurs many benefits can be found in SAE programs. In New York a group of agricultural education teachers rated SAEs as valuable in the development of work attitudes, values and habits; technical 
skills; and of general benefit to the agricultural education program (Berkey and Sutphin, 1984). Rawls (1982) reported that parents recognized the benefits of SAEs to be in areas of work attitude, occupational development, and human relations. Rawls (1982) also concluded that parental support was more likely when they see benefits to their own sons or daughters.

SAEs provide an opportunity for students to earn accolades and be rewarded for their hard work. These accolades help build confidence and fuel a student's motivation to achieve more. Some of these accolades come in the form of degrees. In order to obtain a chapter or state degree students must participate in a SAE (National FFA Organization, 2009). SAE's offer opportunities for all students, however, the percentage of students enrolled in agricultural education that have a SAE has been steadily declining.

\section{Purpose of the Study}

SAEs are a required element to earn any FFA degree (National FFA Organization, 2009, p.22-23). A number of post-secondary education students who were very active and earned many degrees in the FFA were unaware of supervised agriculture experience programs. Students say they were not fully informed on this issue by educators, they were not taught about SAE's (personal communication, September 15, 2009). How are students earning degrees with SAE requirements without knowledge of the SAE concepts?

This study was designed to examine the importance/emphasis agricultural education teachers place on teaching students about SAEs. It is important to know how educators perceive SAEs as a part of the total agriculture education learning experience. Variables that were studied include: (a) educators education background, (b) educators 
definition of a SAE, (c) perceived benefits of SAEs, (d) attitude toward educators job, (e) attitude toward educators role in SAE process, (f) perceived support from students families, (g) attitude toward three part model, classroom/FFA/SAE, and (h) community make up.

The study provided information regarding the importance educators put on teaching and helping students implement SAEs in their program. This information will be valuable in helping educators, state supervisors, and the National FFA Organization develop ways to educate and encourage educators to have students take part in SAEs.

\section{Research Questions}

1. What were the views of agricultural educators about SAEs?

2. What SAE opportunities existed for students?

3. How much emphasis was placed on teaching SAEs in the classroom?

4. Were SAES used as a part of students' final grades?

5. What was the role of parental support in the student having a SAE?

6. Were record keeping skills taught as a part of SAEs?

7. What were teachers' opinions on SAEs being essential to earn degrees and awards in the FFA?

\section{Limitations of the Study}

This study was limited to six states, Kentucky, Maryland, Ohio, Pennsylvania, Virginia, and West Virginia. All current agricultural education teachers in the involved six states were included in the study. 


\section{CHAPTER II}

\section{Review of Literature}

Supervised agriculture experience programs are one of the three components of the total agricultural education program. They cover a wide range of programs offering countless opportunities for students to be involved. Many students actively involved with a SAE often take this beyond their days in an agricultural education setting. SAEs can play a huge role in guiding students down different career and educational paths.

The number of students participating in SAEs has steadily declined over the past 40 years (Cooper \& Nelson, 1981). Many students involved in agricultural education, even post-secondary agricultural education, are unaware of the SAE program and the significant role that it plays in agricultural education. In Tennessee, Lamberth (1986) found that only $35 \%$ of the programs required SAE participation. A Montana based study indicated that nearly one-half of the students were not told of a SAE requirement (Shelhamer, 1984). To be unaware of SAEs there must be a problem in the linkage, a key step is being missed along the way.

Research has been done in many areas relating to SAEs. Areas include the values gained by SAEs as perceived by students, teachers, employers and parents; perceptions regarding SAEs; outcomes of the SAE program; and the relationship of SAE participation and student achievement.

"Learning by doing:" The FFA motto is a perfect example of what SAEs are geared to do, help students gain knowledge by a hands on process. "An ounce of experience is better that a ton of theory simply because it is only in experience that any theory has a vital and verifiable significance" (Dewey, 1916). Giving students the 
opportunity to take what they have learned in the classroom and experience it in a real life situation is a learning tool that agricultural education has implemented into its program.

Previous research on the views of students and parents toward SAEs is extensive. "Parents of vocational agricultural students [sic] recognize the educational and occupational benefits derived from Supervised Occupational Experience programs and will generally support them if they can see the benefits provided to their son or daughter" (Rawls, 1982, p. 38) Rawls (1980) also reported that parents thought students derived three major benefits from SOE: work attitudes, occupational development, and human relation skills.

For any experience to be effective the student must believe they will get something beneficial out of the experience. Results are similar with SAEs. If students do not feel they are gaining worthwhile knowledge, money, accolades...etc., they will not fully participate inhibiting the learning experience. Pals (1988) identified the five greatest student perceived benefits of SAEs. These benefits were (1) an opportunity to learn on own, (2) acceptance of responsibility, (3) develop independence, (4) pride of ownership, and (5) learn to appreciate work (Pals, 1988). SAE experiences can be a gateway to the future for many students who are involved with them. SAEs have helped prepare students for jobs in agriculture (Herren \& Cole, 1984).

With the quality of research focused on students and parents regarding SAEs and the positive feedback one wonders why the number of students with SAEs has been declining. Although there are a number of issues that could be impacting the decline in involvement, this study looked at the role educators may play. 
Teacher attitudes and expectations strongly influence SAE participation.

While teachers claim to support the concept of SAE many fail to implement the programs fully, resulting in decrease participation by students. Participation varies widely by state, is demographically dependent, and is lacking by all parties. (Dyer \& Osborne, 1995, p. 6) You do not have to look far to see how important SAEs are to agricultural education and the FFA. The FFA website and the information contained within shows the “Three Ring Model.” Research, however, shows that many students are not taking part in a SAE program (Dyer \& Osborne, 1995). It has been reported that less than $30 \%$ of students in the state of New York had SAE projects (Penrod, 1985) In California it was reported that as many as $43 \%$ of students had no SAE program (Leising \& Zilbert, 1985) and in Florida it was found that less than half the students that had been involved in agricultural education programs for all four years of school had been involved in a SAE program (Arrington, 1985).

By contrast some states have shown a much higher percentage of participation when those states were involved in research. It was reported that a high percentage of Colorado students participated in a SAE program (McCall, 1983). In Areas I and II in Texas, $58 \%$ of the agriculture departments reported that every student was involved in a SAE program (Harris \& Newcomb, 1985). There are many different variables that could impact the differences from region to region. However, across the board there is a decline taking place.

As attention turns toward the educators to educate students on SAEs and help bring up the numbers it is helpful to look at their role in the SAE process. The 
experience, training, previous knowledge, and interactions with SAEs can play a role in student participation. Bobbitt (1986) found that rural teachers placed more emphasis on SAE programs that did urban teachers. He also reported that older teachers had more students in farm-oriented SAEs, whereas younger teachers had more of their students in land laboratories. In a study on first and second year teachers and what they considered to be highest priority items, it was reported that working with SAEs was third and working with SAE records to be the fourth priority behind teaching classes and working with FFA activities (Johnson, Lindhart, \& Stewart, 1989).

A teacher's attitude toward SAEs is a key factor in student participation in SAEs. Research by Arrington and Price (1983), Berkey and Sutphin (1984), Harris and Newcomb (1985), Iverson (1980), and Osborne (1998) indicate that teachers support the concept of SAE programs; however they have difficulty implementing programs with students. Studies have found significant relationships between the number of students participating in SAEs and teacher attitude (Reneau \& Rider, 1986). Teachers in departments with strong SAE programs emphasize SAEs more than teachers in departments with weak SAE programs (Herren \& Cole 1984).

For SAE programs to be successful participation from all parties involved is needed. However agricultural education teachers are perceived as having a major responsibility for ensuring success. Foster (1986) reported that the most important deterrents to student participation were the lack of facilities, student desire, and teacher time for supervision. Many educators reported that the SAE assistance they provide as being inadequate (Lamberth, 1986). 


\section{Summary}

Studies relating to SAEs in agricultural education and the research questions posed for this study vary in age. Due to changes in academic requirements, teacher turnover, record keeping practices and requirements for degrees continuing research in this area is important. "One problem we face is that dramatic changes in agriculture and agricultural education have caused a lack of focus and direction in SAE" (Dyer \& Osborne, 1996). Camp, Clarke and Fallon (2000) stated that "SAE remains a viable component of a comprehensive program of agricultural education but that its definition needs to be broadened and that its structure needs substantial expansion to accommodate the realities facing agricultural educators today" (p. 13). SAE research can help promote agricultural education and its learning outcomes along with providing valuable information to the National FFA Organization on this program. 


\section{CHAPTER III}

\section{Methodology}

\section{Purpose of the study}

SAEs are a required element to earn any FFA degree (National FFA Organization, 2009). A number of post-secondary education students who were very active and earned many degrees in the FFA were unaware of supervised agriculture experience programs (personal communication, September 15, 2009). Students say they were not fully informed on this issue by educators, they were not taught about SAE's. How are students earning degrees with SAE requirements without knowledge of the SAE concepts?

This study was designed to examine the importance/emphasis agricultural education teachers place on teaching students about SAEs. It is important to know how educators perceive SAEs as a part of the total agriculture education learning experience. Variables that will be studied include: (a) educators education background, (b) educators definition of a SAE, (c) perceived benefits of SAEs, (d) attitude toward educators job, (e) attitude toward educators role in SAE process, (f) perceived support from students families, (g) attitude toward three part model, Classroom/FFA/SAE, and (h) community make up.

The study will provide information regarding the importance educators put on teaching and helping students implement SAEs in their program. This information will be valuable in helping educators, state supervisors, and the National FFA Organization develop ways to educate and encourage educators to have students take part in SAEs. 


\section{Research Questions}

1. What were the views of agricultural educators about SAEs?

2. What SAE opportunities existed for students?

3. How much emphasis was placed on teaching SAEs in the classroom?

4. Were SAES used as a part of students' final grades?

5. What was the role of parental support in the student having a SAE?

6. Were record keeping skills taught as a part of SAEs?

7. What were teachers' opinions on SAEs being essential to earn degrees and awards in the FFA?

\section{Research Design}

A descriptive survey research design in the form of an electronic questionnaire was used to obtain data for this study. Ary, Jacobs, and Razavick (1992) describe descriptive research studies as those studies that “....are designed to obtain information concerning the current status of phenomena" (p. 322). Descriptive research was found to be the best method to use because of the type of information being collected. Looking at real life data and opinions of individuals are an appropriate use of descriptive research.

Descriptive research is usually conducted in a natural setting with mail questionnaires, interviews or telephone. In this research, current technologies in the form of an online electronic survey were used to collect information.

\section{Population}

The target population of the research was all agricultural education teachers in the states of Kentucky, Maryland, Ohio, Pennsylvania, Virginia and West Virginia. The 
accessible population was all current agricultural teachers in those states that were employed Spring 2010 and could be reached by e-mail.

A purposeful sample of student teachers that had been in the field within the past one and one-half years was used for a pilot study of the instrumentation. The pilot test sample was selected because this group was accessible, experienced, knowledgeable and in final stages of working toward teacher certification.

By conducting a census of the accessible population sampling error was avoided. Selection error was avoided by using official lists of all current agricultural education teachers in the states involved. Measurement error was avoided by using a valid and reliable instrument.

Non-response error was examined by comparing early and late respondents on three key demographic variables. No differences were found between the groups, however because of the response rate, the researcher elected to limit conclusions to the individuals who responded to the survey.

\section{Instrumentation}

The research instrument was developed by reviewing past instruments and research relating to the topic. Using this information questions were developed for the instrument. The instrument was composed of three types of questions; open ended, multiple response and Likert scale. Research questions were directed at requirements of SAEs that may affect the importance or emphasis an educator may place on SAEs in the

agricultural education system. Areas included the value of SAEs, opportunities provided by SAEs, time requirements with SAEs, thoughts and opinions related to SAEs, SAE 
requirements and recognition. The educators' competences in teaching SAEs and community support along with the agricultural education program were also examined.

\section{Reliability/Validity}

The instrument was presented to a panel of experts to establish its content and face validity. The panel consisted of teacher educators in Agricultural and Extension Education at West Virginia University. Each one of these individuals has had extensive teaching and/or Extension field experience. They possessed many leadership skills and have extensive experience in research design. The panel of experts concluded that the instrument had content and face validity.

Reliability of the instrument was established using the entire data set and the Statistical Package for Social Sciences' (SPSS). The Likert-type items were tested for reliability using the split-half statistic coefficient. The unequal-length Spearman-Brown value was found to be .86 for the instrument making reliability of the instrument exemplary (Robinson, Shaver, \& Wrightsman, 1991). The instrument was established to be reliable.

\section{Data Collection Procedures}

Dillman's Tailored Design Method (2007) was used to collect data. An initial emailing was sent out with a cover letter and link to the instrument. Respondents were given 10 days to respond. At the end of 10 days a second mailing was sent and once again respondents were given 10 days to respond. A follow up e-mail was sent three days before the second deadline. After the second deadline a third e-mail was sent giving respondents three days to respond. After the third mailing deadline the fourth and final e- 
mail asking agricultural education teachers to respond was sent out with a five day deadline.

\section{Analysis of Data}

Returned questionnaires were retrieved from the online system into an Excel spreadsheet. The data was transferred to the personal computer version of the Statistical Package for the Social Sciences (SPSS). The level of significance was set a priori at $\alpha$ $\leq .05$ for all statistical tests. Descriptive analyses were performed on the data. Frequency tables were used for Likert items.

\section{Use of Findings}

The findings can be used by agricultural educators, state supervisors, students and the National FFA organization to assess teacher perceptions toward SAE's. This study provided information needed to consider potential changes to SAEs and their role in FFA awards. Through this study one can look at the views toward SAEs in their current format. 


\section{CHAPTER IV}

\section{Findings}

\section{Purpose and Objectives}

The purpose of this study was to determine the emphasis and importance agricultural education teachers place on supervised agricultural experiences in agricultural education programs. It was also designed to look at reasons educators encourage students to take part in SAEs. This study will be helpful in providing information to agricultural teachers, state supervisors and students.

The objectives of the study are reflected in the following research questions:

1. What were the views of agricultural educators about SAEs?

2. What SAE opportunities existed for students?

3. How much emphasis was placed on teaching SAEs in the classroom?

4. Were SAES used as a part of students' final grades?

5. What was the role of parental support in the student having a SAE?

6. Were record keeping skills taught as a part of SAEs?

7. What were teachers' opinions on SAEs being essential to earn degrees and awards in the FFA?

\section{Population}

The accessible population consisted of 1,500 agricultural education teachers employed in Kentucky, Maryland, Ohio, Pennsylvania, Virginia and West Virginia during the spring of 2010. Three hundred ninety-one questionnaires were completed for a $26.1 \%$ response rate. 


\section{Demographic Characteristics of Respondents}

Of the respondents 63 (16.1\%) were from Kentucky. Seventeen respondents (4.3\%) taught in Maryland while 106 (27.1\%) were from Ohio. Fifty-eight respondents (14.8\%) were from Pennsylvania, while 18 (4.6\%) were from Virginia. A total of 47 respondents (12.0\%) indicated that they were teaching in West Virginia. Eighty-two respondents $(21.0 \%)$ did not indicate the current state in which they were teaching (see Table 1).

Table 1

Number of Agricultural Education Teachers Who Responded to Survey

\begin{tabular}{lcc}
\hline & $\mathrm{N}$ & $\%$ \\
\hline Kentucky & 63 & 16.1 \\
Maryland & 17 & 4.3 \\
Ohio & 106 & 27.1 \\
Pennsylvania & 58 & 14.8 \\
Virginia & 18 & 4.6 \\
West Virginia & 47 & 12.0 \\
State not reported & 82 & 21.0 \\
\hline
\end{tabular}

One hundred ninety-one $(60.6 \%)$ of the respondents indicated that they were male and $124(39.4 \%)$ female. Of the respondents from Kentucky 43 (68.3\%) were male and $20(31.7 \%)$ female. Nine respondents (52.9\%) from Maryland were male and $8(47.1 \%)$ were female. Ohio respondents indicated that 62 (58.5\%) were male with $44(41.5 \%)$ being female. Thirty-three respondents (56.9\%) from Pennsylvania were male with 25 (43.1\%) female. Virginia respondents indicated that 5 (29.4\%) were male and 12 
(70.6\%) were female. Thirty-three respondents (70.2\%) from West Virginia were male and $14(29.8 \%)$ were female. Of the respondents whose state was not reported four $(80.0 \%)$ were male with one (20.0\%) was female (see Table 2).

Table 2

Gender of Survey Participants

\begin{tabular}{lrcrc}
\hline & \multicolumn{3}{c}{ Male } & \multicolumn{2}{c}{ Female } \\
\cline { 2 - 5 } & $\mathrm{N}$ & $\%$ & $\mathrm{~N}$ & $\%$ \\
\hline Kentucky & 43 & 68.3 & 20 & 31.7 \\
Maryland & 9 & 52.9 & 8 & 47.1 \\
Ohio & 62 & 58.5 & 44 & 41.5 \\
Pennsylvania & 33 & 56.9 & 25 & 43.1 \\
Virginia & 5 & 29.4 & 12 & 70.6 \\
West Virginia & 33 & 70.2 & 14 & 29.8 \\
State not reported & 4 & 80.0 & 1 & 20.0 \\
Total & 191 & 60.6 & 124 & 39.4 \\
\hline
\end{tabular}

Using five categories participants were asked to indicate their age. A total of 97 (30.8\%) participants indicated they were 21-30 years of age. Seventy-seven respondents (24.4\%) identified they were in the 31-40 year old age range. Sixty-one respondents (19.4\%) indicated they were 41-50 years old, while 67 (21.3\%) respondents identified they were 51-60 years old. The 60 years and over category included 13 respondents (4.1\%) (see Table 3). 
Table 3

Age of Agricultural Education Teachers

\begin{tabular}{lcccccccccc}
\hline & & & & & & & \multicolumn{3}{c}{$\begin{array}{c}60 \text { years and } \\
\text { over }\end{array}$} \\
\cline { 2 - 10 } & $\mathrm{N}$ & $\%$ & $\mathrm{~N}$ & $\%$ & $\mathrm{~N}$ & $\%$ & $\mathrm{~N}$ & $\%$ & $\mathrm{~N}$ & $\%$ \\
\hline Kentucky & 25 & 39.7 & 14 & 22.2 & 10 & 15.9 & 13 & 20.6 & 1 & 1.6 \\
Maryland & 5 & 29.4 & 4 & 23.5 & 3 & 17.6 & 3 & 17.6 & 2 & 11.8 \\
Ohio & 30 & 28.3 & 33 & 31.1 & 17 & 16.0 & 22 & 20.8 & 4 & 3.8 \\
Pennsylvania & 22 & 37.9 & 8 & 13.8 & 12 & 20.7 & 14 & 24.1 & 2 & 3.4 \\
Virginia & 3 & 17.6 & 3 & 17.6 & 8 & 47.1 & 2 & 11.8 & 1 & 5.9 \\
West Virginia & 11 & 23.4 & 14 & 29.8 & 11 & 23.4 & 8 & 17.0 & 3 & 6.4 \\
$\begin{array}{l}\text { State not } \\
\text { reported }\end{array}$ & 1 & 20.0 & 1 & 20.0 & 0 & .0 & 3 & 60.0 & 0 & .0 \\
\begin{tabular}{l} 
Total \\
\hline
\end{tabular} & 97 & 30.8 & 77 & 24.4 & 61 & 19.4 & 67 & 21.3 & 13 & 4.1 \\
\hline
\end{tabular}

Using seven categories participants were asked to indicate their years of teaching experience. Sixteen $(5.1 \%)$ of the respondents indicated they had less than one year of experience, while $71(22.6 \%)$ identified themselves as having 1-5 years of experience. Sixty-two respondents (19.7\%) indicated they had 6-10 years of teaching experience with $42(13.4 \%)$ identifying with the $11-15$ years of experience group. The 16-20 years category included 24 respondents (7.6\%), while 34 (10.8) indicated they had 21-25 years of teaching experience. The final category, more than 25 years of teaching, had 65 respondents $(20.7 \%)$ (see Table 4$)$. 
Table 4

Years of Agricultural Education Teaching Experience Reported by Research Participants

\begin{tabular}{|c|c|c|c|c|c|c|c|c|c|c|c|c|c|c|}
\hline & \multicolumn{2}{|c|}{$\begin{array}{c}\text { Less than one } \\
\text { year }\end{array}$} & \multicolumn{2}{|c|}{$1-5$ years } & \multicolumn{2}{|c|}{$6-10$ years } & \multicolumn{2}{|c|}{ 11-15 years } & \multicolumn{2}{|c|}{$16-20$ years } & \multicolumn{2}{|c|}{ 21-25 years } & \multicolumn{2}{|c|}{$\begin{array}{c}\text { More than } 25 \\
\text { years }\end{array}$} \\
\hline & $\mathrm{N}$ & $\%$ & $\mathrm{~N}$ & $\%$ & $\mathrm{~N}$ & $\%$ & $\mathrm{~N}$ & $\%$ & $\mathrm{~N}$ & $\%$ & $\mathrm{~N}$ & $\%$ & $\mathrm{~N}$ & $\%$ \\
\hline Kentucky & 4 & 6.3 & 18 & 28.6 & 11 & 17.5 & 9 & 14.3 & 5 & 7.9 & 9 & 14.3 & 7 & 11.1 \\
\hline Maryland & 2 & 11.8 & 3 & 17.6 & 5 & 29.4 & 1 & 5.9 & 0 & .0 & 1 & 5.9 & 5 & 29.4 \\
\hline Ohio & 3 & 2.8 & 27 & 25.5 & 22 & 20.8 & 15 & 14.2 & 7 & 6.6 & 11 & 10.4 & 21 & 19.8 \\
\hline Pennsylvania & 3 & 5.2 & 10 & 17.2 & 14 & 24.1 & 8 & 13.8 & 7 & 12.1 & 2 & 3.4 & 14 & 24.1 \\
\hline Virginia & 1 & 6.3 & 2 & 12.5 & 3 & 18.8 & 1 & 6.3 & 2 & 12.5 & 4 & 25.0 & 3 & 18.8 \\
\hline West Virginia & 3 & 6.4 & 9 & 19.1 & 6 & 12.8 & 8 & 17.0 & 3 & 6.4 & 7 & 14.9 & 11 & 23.4 \\
\hline $\begin{array}{l}\text { State not } \\
\text { reported }\end{array}$ & 0 & .0 & 2 & 40.0 & 1 & 20.0 & 0 & .0 & 0 & .0 & 0 & .0 & 2 & 40.0 \\
\hline Total & 16 & 5.1 & 71 & 22.6 & 62 & 19.7 & 42 & 13.4 & 24 & 7.6 & 34 & 10.8 & 65 & 20.7 \\
\hline
\end{tabular}


Of the respondents $240(75.9 \%)$ indicated they grew up in a rural-farm area, while $53(16.8 \%)$ grew up in a rural-nonfarm setting. Seventeen respondents $(5.4 \%)$ grew up in a suburban area and six individuals indicated they grew up in an urban setting (see Table 5). Respondents were also asked to indicate the type of school district in which they teach. Of the respondents $153(48.4 \%)$ indicated they taught in a rural-farm district. One hundred nineteen individuals (37.7\%) taught in a rural-nonfarm area, while $35(11.1 \%)$ of respondents taught in a suburban school district. Nine respondents $(2.8 \%)$ indicate they taught in an urban school district (see Table 6).

Table 5

Area Agricultural Education Teachers Grew Up

\begin{tabular}{lcccccccc}
\hline & \multicolumn{2}{c}{ Rural- Farm } & \multicolumn{2}{c}{ Rural- Non-farm } & \multicolumn{2}{c}{ Suburban } & \multicolumn{2}{c}{ Urban } \\
\cline { 2 - 8 } & $\mathrm{N}$ & $\%$ & $\mathrm{~N}$ & $\%$ & $\mathrm{~N}$ & $\%$ & $\mathrm{~N}$ & $\%$ \\
\hline Kentucky & 51 & 81.0 & 9 & 14.3 & 2 & 3.2 & 1 & 1.6 \\
Maryland & 10 & 58.8 & 3 & 17.6 & 3 & 17.6 & 1 & 5.9 \\
Ohio & 86 & 81.1 & 14 & 13.2 & 6 & 5.7 & 0 & .0 \\
Pennsylvania & 41 & 70.7 & 15 & 25.9 & 2 & 3.4 & 0 & .0 \\
Virginia & 12 & 66.7 & 3 & 16.7 & 2 & 11.1 & 1 & 5.6 \\
West Virginia & 35 & 74.5 & 8 & 17.0 & 2 & 4.3 & 2 & 4.3 \\
$\begin{array}{l}\text { State not } \\
\text { reported }\end{array}$ & 3 & 60.0 & 1 & 20.0 & 0 & .0 & 1 & 20.0 \\
$\begin{array}{l}\text { Total } \\
\text { Thy }\end{array}$ & 240 & 75.9 & 53 & 16.8 & 17 & 5.4 & 6 & 1.9 \\
\hline
\end{tabular}


Table 6

Type of School District Served by the Agricultural Education Teachers

\begin{tabular}{lcccccccc}
\hline & \multicolumn{2}{c}{ Rural- Farm } & \multicolumn{2}{c}{ Rural- Non-farm } & \multicolumn{2}{c}{ Suburban } & \multicolumn{2}{c}{ Urban } \\
\cline { 2 - 9 } & $\mathrm{N}$ & $\%$ & $\mathrm{~N}$ & $\%$ & $\mathrm{~N}$ & $\%$ & $\mathrm{~N}$ & $\%$ \\
\hline Kentucky & 34 & 54.0 & 21 & 33.3 & 7 & 11.1 & 1 & 1.6 \\
Maryland & 4 & 23.5 & 8 & 47.1 & 4 & 23.5 & 1 & 5.9 \\
Ohio & 54 & 50.9 & 38 & 35.8 & 9 & 8.5 & 5 & 4.7 \\
Pennsylvania & 29 & 50.0 & 22 & 37.9 & 7 & 12.1 & 0 & .0 \\
Virginia & 4 & 22.2 & 12 & 66.7 & 2 & 11.1 & 0 & .0 \\
West Virginia & 26 & 55.3 & 16 & 34.0 & 4 & 8.5 & 1 & 2.1 \\
$\begin{array}{l}\text { State not } \\
\text { reported }\end{array}$ & 1 & 20.0 & 1 & 20.0 & 2 & 40.0 & 1 & 20.0 \\
Total & 153 & 48.4 & 119 & 37.7 & 35 & 11.1 & 9 & 2.8 \\
\hline
\end{tabular}

\section{Statements Concerning the Values of SAEs}

The respondents were asked their opinions on a number of factors that affect their views and the importance and emphasis they place on SAEs in their agricultural education program. The questions were grouped into ten different categories. Respondents expressed their opinions using a four point Likert scale, the items were recoded making 1 "strongly disagree", 2 "disagree", 3 "agree" and 4 "strongly agree." Thirteen questions were based around the values of SAEs in agricultural education.

Two hundred and eighty-one respondents (72.1\%) strongly agreed that SAE's were a valuable component of agricultural education. One hundred respondents $(25.6 \%)$ agreed with the statement, while six respondents (1.5\%) disagreed and three respondents (.8\%) strongly disagreed (see Table 7). 
Two hundred ninety respondents (74.2\%) strongly agreed that SAE's were a valuable learning experience for students in agricultural education. Ninety-four respondents (24.0\%) agreed with the statement while four $(1.0 \%)$ disagreed and three respondents $(0.8 \%)$ strongly disagreed.

When asked if participation in SAEs improved students' attitudes toward nonschool related work, 215 respondents (55.6\%) strongly agreed, while 141 respondents (36.4\%) agreed. Twenty-eight respondents (7.2\%) disagreed and three (0.8\%) strongly disagreed. Two hundred eighty-eight respondents (73.7\%) strongly agreed that SAEs were a valuable way to promote experiential (hands on) learning, while 91 (23.3\%) agreed. Nine respondents $(2.3 \%)$ disagreed and $3(0.8 \%)$ strongly disagreed.

Two hundred twenty-five respondents strongly agreed that SAE record keeping was valuable to the students' futures. One hundred forty-three respondents (37.6\%) agreed, while $12(3.2 \%)$ disagreed. None of the respondents $(0.0 \%)$ strongly disagreed with the statement.

Two hundred fifty-four respondents (66.8\%) strongly agreed that SAEs were an educational tool that provided life-long learning. One hundred seventeen respondents (30.8\%) agreed, while eight (2.1\%) disagreed and one individual (0.3\%) strongly disagreed.

When asked whether grades should be used to encourage student participation in SAEs, 174 respondents (45.9\%) indicated that they strongly agreed with the statement and $142(37.5 \%)$ agreed. Fifty-seven respondents (15.0\%) disagreed, while six (1.6\%) indicated they strongly disagreed. 
One hundred sixty-one respondents (42.9\%) strongly agreed with the statement that as an agriculture teacher they incorporated SAEs into their student grades, while 126 respondents (33.6\%) agreed. Seventy-four respondents (19.7\%) disagreed and 14 respondents $(3.7 \%)$ strongly disagreed with the statement.

Two hundred eighteen respondents (58.1\%) strongly agreed that SAEs helped to develop competencies in agriculture. One hundred forty-four respondents $(38.4 \%)$ agreed with the statement, while 12 respondents $(3.2 \%)$ disagreed and one $(0.1 \%)$ strongly disagreed.

One hundred seventy-one respondents (45.4\%) strongly agreed that students should earn graduation credits for their SAEs, while 140 (37.1\%) indicated they agreed with this statement. Fifty-four respondents (14.3\%) agreed with the statement and 12 (3.4\%) strongly disagreed.

One hundred twenty educators (32.6\%) strongly agreed with the statement that students receive academic credit (credit toward graduation) each year for successfully completing an approved supervised experience program. Of the respondents eighty-two (22.3\%) agreed, while 116 respondents (31.5\%) disagreed. Fifty respondents $(13.6 \%)$ indicated they strongly disagreed with the statement.

Three respondents $(0.8 \%)$ strongly agreed with the statement that the only successful SAEs are those in which the student makes a monetary profit. Ten respondents $(2.6 \%)$ agreed with the statement while 179 educators $(47.2 \%)$ indicated they disagreed. One hundred eighty-seven respondents (49.3\%) indicated they strongly disagreed with the statement. 
Table 7

Responses to Selected Statements Concerning the Value of SAEs

\begin{tabular}{|c|c|c|c|c|c|c|c|c|}
\hline & \multicolumn{2}{|c|}{ Strongly Disagree } & \multicolumn{2}{|c|}{ Disagree } & \multicolumn{2}{|c|}{ Agree } & \multicolumn{2}{|c|}{ Strongly Agree } \\
\hline & $\mathrm{N}$ & $\%$ & $\mathrm{~N}$ & $\%$ & $\mathrm{~N}$ & $\%$ & $\mathrm{~N}$ & $\%$ \\
\hline $\begin{array}{l}\text { SAE's are a valuable component of agricultural } \\
\text { education }\end{array}$ & 3 & .8 & 6 & 1.5 & 100 & 25.6 & 281 & 72.1 \\
\hline $\begin{array}{l}\text { SAE's are a valuable learning experience for } \\
\text { students in agricultural education }\end{array}$ & 3 & .8 & 4 & 1.0 & 94 & 24.0 & 290 & 74.2 \\
\hline $\begin{array}{l}\text { Participation in SAEs improves students' attitudes } \\
\text { toward non-school related work }\end{array}$ & 3 & .8 & 28 & 7.2 & 141 & 36.4 & 215 & 55.6 \\
\hline $\begin{array}{l}\text { SAEs are a valuable way to promote experiential } \\
\text { (hands on) learning }\end{array}$ & 3 & .8 & 9 & 2.3 & 91 & 23.3 & 288 & 73.7 \\
\hline $\begin{array}{l}\text { SAE record keeping is valuable to the students' } \\
\text { future }\end{array}$ & 0 & .0 & 12 & 3.2 & 143 & 37.6 & 225 & 59.2 \\
\hline $\begin{array}{l}\text { SAEs are an educational tool that provides life-long } \\
\text { learning }\end{array}$ & 1 & .3 & 8 & 2.1 & 117 & 30.8 & 254 & 66.8 \\
\hline Grades should be used to encourage student SAEs & 6 & 1.6 & 57 & 15.0 & 142 & 37.5 & 174 & 45.9 \\
\hline $\begin{array}{l}\text { As an agriculture teacher I incorporate SAEs into } \\
\text { my student grades }\end{array}$ & 14 & 3.7 & 74 & 19.7 & 126 & 33.6 & 161 & 42.9 \\
\hline
\end{tabular}


Table 7 (Continued)

Responses to Selected Statements Concerning the Value of SAEs

\begin{tabular}{|c|c|c|c|c|c|c|c|c|}
\hline & \multicolumn{2}{|c|}{ Strongly Disagree } & \multicolumn{2}{|c|}{ Disagree } & \multicolumn{2}{|c|}{ Agree } & \multicolumn{2}{|c|}{ Strongly Agree } \\
\hline & $\mathrm{N}$ & $\%$ & $\mathrm{~N}$ & $\%$ & $\mathrm{~N}$ & $\%$ & $\mathrm{~N}$ & $\%$ \\
\hline SAEs help to develop competencies in agriculture & 1 & .3 & 12 & 3.2 & 144 & 38.4 & 218 & 58.1 \\
\hline $\begin{array}{l}\text { Students should earn graduation credits for their } \\
\text { SAEs }\end{array}$ & 12 & 3.2 & 54 & 14.3 & 140 & 37.1 & 171 & 45.4 \\
\hline $\begin{array}{l}\text { My students receive academic credit (credit towarc } \\
\text { graduation) each year for successfully completing } \\
\text { an approved supervised experience program }\end{array}$ & 50 & 13.6 & 116 & 31.5 & 82 & 22.3 & 120 & 32.6 \\
\hline $\begin{array}{l}\text { The only successful SAEs are those in which the } \\
\text { student makes a monetary profit }\end{array}$ & 187 & 49.3 & 179 & 47.2 & 10 & 2.6 & 3 & .8 \\
\hline SAEs increase student interest in agriculture & 3 & .8 & 38 & 10.1 & 184 & 48.8 & 152 & 40.3 \\
\hline
\end{tabular}


One hundred fifty-two respondents $(40.3 \%)$ responded to the statement that SAEs increase student interest in agriculture by stating they strongly agreed. One hundred eighty-four respondents (48.8\%) agreed with the statement, while 38 (10.1\%) disagreed and three $(0.8 \%)$ strongly disagreed (see Table 7$)$.

Composite score averages for all statements regarding the value of SAEs was calculated. Respondents averaged $3.27(S D=.45)$ on the composite score, showing an agreement level between "Agree" and "Strongly Agree." Virginia showed the lowest level of agreement $(M=3.04)$ and West Virginia had the highest level of agreement $(M$ $=3.48)$ (see Table 8).

Table 8

Composite Score Averages for Selected Statements on the Value of SAEs

\begin{tabular}{lcc}
\hline & $M$ & $S D$ \\
\hline Kentucky & 3.18 & .33 \\
Maryland & 3.26 & .32 \\
Ohio & 3.37 & .40 \\
Pennsylvania & 3.21 & .48 \\
Virginia & 3.04 & .54 \\
West Virginia & 3.48 & .33 \\
State not reported & 3.20 & .55 \\
All Participants & 3.27 & .45 \\
\hline
\end{tabular}

\section{Opportunities Provided by SAEs}

Seven statements regarding opportunities provided by SAEs were presented to the respondents. A majority of the respondents $(N=359,95.9 \%)$ agreed that SAEs gave 
agricultural education students opportunities that other students did not receive with 207 (55.3\%) expressed strong agreement. One hundred fifty-two individuals (40.6\%) indicated they agreed while $15(4.0 \%)$ disagreed.

One hundred ninety respondents $(51.2 \%)$ strongly agreed with the statement that SAE opportunities were available to all students in their program while 137 (36.9\%) agreed. Thirty-seven respondents (10.0\%) indicated they disagreed and seven (1.9\%) strongly disagreed with the statement.

Two hundred five respondents (55.4\%) strongly agreed with the statement that they teach all students in their program about SAEs while 127 respondents (34.3\%) agreed with the statement. Thirty-four respondents $(9.2 \%)$ disagreed with the statement while four individuals (1.1\%) strongly disagreed with the statement.

Two hundred twenty-seven respondents (61.4\%) strongly agreed with the statement that students in their program have the opportunity to use off-farm placement as a SAE while $126(34.1 \%)$ agreed. Fourteen respondents (3.8\%) disagreed with the statement while three $(0.8 \%)$ strongly disagreed with the statement.

Two hundred thirty respondents (61.8\%) strongly agreed with the statement that students in their program have the opportunity to use farm placement as a SAE while 117 (31.5\%) agreed with the statement. Twenty-one respondents (5.6\%) indicted that they disagreed with the statement. Four respondents (1.1\%) indicated a strong disagreement with the statement. 
Table 9

Responses to Selected Statements Concerning Opportunities Provided by SAEs

\begin{tabular}{|c|c|c|c|c|c|c|c|c|}
\hline & \multicolumn{2}{|c|}{ Strongly Disagree } & \multicolumn{2}{|c|}{ Disagree } & \multicolumn{2}{|c|}{ Agree } & \multicolumn{2}{|c|}{ Strongly Agree } \\
\hline & $\mathrm{N}$ & $\%$ & $\mathrm{~N}$ & $\%$ & $\mathrm{~N}$ & $\%$ & $\mathrm{~N}$ & $\%$ \\
\hline $\begin{array}{l}\text { SAEs give agricultural education students } \\
\text { opportunities that other students do not receive }\end{array}$ & 0 & .0 & 15 & 4.0 & 152 & 40.6 & 207 & 55.3 \\
\hline $\begin{array}{l}\text { SAE opportunities are available to all students in } \\
\text { my program }\end{array}$ & 7 & 1.9 & 37 & 10.0 & 137 & 36.9 & 190 & 51.2 \\
\hline I teach all students in my program about SAEs & 4 & 1.1 & 34 & 9.2 & 127 & 34.3 & 205 & 55.4 \\
\hline $\begin{array}{l}\text { Students in my program have the opportunity to } \\
\text { use off-farm placement as a SAE }\end{array}$ & 3 & .8 & 14 & 3.8 & 126 & 34.1 & 227 & 61.4 \\
\hline $\begin{array}{l}\text { Students in my program have the opportunity to } \\
\text { use farm placement as a SAE }\end{array}$ & 4 & 1.1 & 21 & 5.6 & 117 & 31.5 & 230 & 61.8 \\
\hline $\begin{array}{l}\text { Opportunities for SAEs are limited in my } \\
\text { community }\end{array}$ & 50 & 13.5 & 163 & 43.9 & 121 & 32.6 & 37 & 10.0 \\
\hline $\begin{array}{l}\text { A SAE should help prepare students for their } \\
\text { career occupational goal }\end{array}$ & 2 & .5 & 60 & 16.0 & 212 & 56.7 & 100 & 26.7 \\
\hline
\end{tabular}


Thirty-seven educators $(10.0 \%)$ strongly agreed with the statement that opportunities for SAEs were limited in their community while 121 (32.6\%) agreed. One hundred sixtythree respondents (43.9\%) expressed disagreement with the statement while $50(13.5 \%)$ indicated they strongly disagreed.

When presented with the statement that a SAE should help prepare students for their career occupational goal, 100 respondents (26.7\%) strongly agreed with the statement. Two hundred twelve respondents (56.7\%) indicated they agreed with the statement while 60 respondents $(16.0 \%)$ disagreed with the statement. Two respondents $(0.5 \%)$ indicated that they strongly disagreed with the statement (see Table 9$)$.

Composite score averages for the seven statements on the opportunities provided by SAEs were calculated. The average for the group was $3.27(S D=.36)$ indicating that respondents showed a level of agreement between "agree" and "strongly agree."

Maryland and Pennsylvania had the lowest level of agreement with an average of 3.20. West Virginia had the highest level of agreement with an average of 3.36 (see Table 10). Time Issues Associated with SAEs

The respondents were presented with 13 questions relating to time issues involved with SAEs in agricultural education. Thirty respondents $(8.2 \%)$ indicated they strongly agreed with the statement that they hold meetings with parents-guardians to explain the purpose, values, and types of SAEs. One hundred fifty-eight respondents (43.3\%) agreed with this statement, while 143 (39.2\%) disagreed. Thirty-four respondents $(9.3 \%)$ indicated they strongly disagreed with this statement. 
Table 10

Composite Score Averages for Selected Statements on Opportunities Provided by SAEs

\begin{tabular}{lcc}
\hline & $M$ & $S D$ \\
\hline Kentucky & 3.26 & .33 \\
Maryland & 3.20 & .23 \\
Ohio & 3.33 & .37 \\
Pennsylvania & 3.20 & .34 \\
Virginia & 3.22 & .43 \\
West Virginia & 3.36 & .33 \\
State not reported & 3.22 & .39 \\
All Participants & 3.27 & .36 \\
\hline
\end{tabular}

Eighty-two respondents $(22.7 \%)$ strongly agreed with the statement that they conduct visits to prospective students to explain the purpose, values, and types of SAEs while $153(42.3 \%)$ agreed with the statement. One hundred thirteen respondents $(31.2 \%)$ disagreed with this statement while 14 (3.9\%) strongly disagreed.

When presented with the statement that agriculture teachers were responsible for supervision of students' SAE programs, 173 (47.0\%) strongly agreed. One hundred seventy-nine respondents $(48.6 \%)$ indicated they agreed with the statement while 13 $(3.5 \%)$ disagreed. Three respondents $(.8 \%)$ strongly disagreed with this statement.

One hundred seventy-two respondents (47.1\%) strongly agreed with the statement that SAE records were kept on a calendar year basis. One hundred fifty-eight 
respondents (43.3\%) agreed with this statement while $30(8.2 \%)$ disagreed. Five respondents (1.4\%) indicated they strongly disagreed with this statement.

Thirty-five respondents $(9.7 \%)$ indicated they strongly agreed with the statement that there were not too many students in their program to supervise everyone that has a SAE while 182 (50.2\%) agreed. One hundred ten respondents (30.4\%) disagreed with the statement and $35(9.7 \%)$ indicated they strongly disagreed.

One hundred fifty-eight respondents (43.6\%) strongly agreed with the statement that they spend time in the classroom teaching SAE record keeping. A total of 170 respondents $(47.0 \%)$ indicated they agreed while 29 (8.0\%) disagreed. Five respondents $(1.4 \%)$ replied that they strongly disagreed with this statement.

One hundred five respondents (28.8\%) strongly agreed with the statement that they use class time to supervise SAE record keeping while $180(49.5 \%)$ responding they agreed with the statement. Sixty-two respondents (17.0\%) disagreed while $17(4.7 \%))$ strongly disagreed with this statement.

One hundred twenty-four respondents (33.9\%) strongly agreed with the statement that they were willing to take extra time to make sure students' SAEs are being properly supervised. Two hundred twelve respondents (57.9\%) agreed with this statement while $28(7.7 \%)$ disagreed. Two respondents $(0.5 \%)$ indicated they strongly disagreed with this statement.

One hundred seven respondents $(29.2 \%)$ said they strongly agreed with the statement that they kept SAE visitation records for their program. One hundred seventyindividuals (46.4\%) agreed with this statement while $80(21.9 \%)$ responded that they disagreed. Nine educators $(2.5 \%)$ indicated they strongly disagreed with this statement. 
When presented with the statement that they spent extra time teaching SAE concepts to freshman 156 respondents (44.4\%) strongly agreed while $142(40.5 \%)$ agreed. Thirty-nine respondents (11.1\%) disagreed with this statement. Fourteen educators $(4.0 \%)$ indicated they strongly disagreed with this statement.

One hundred fifty-four respondents (42.4\%) strongly agreed with the statement that SAEs were worth the extra effort required of the agricultural educator. One hundred eighty-three respondents (50.4\%) agreed with statement while 24 (6.6\%) disagreed. Only two respondents $(0.6 \%)$ indicated they strongly disagreed when presented with the statement.

Twenty respondents (5.5\%) strongly agreed with the statement that during the school year they were allotted release time from school to supervise students SAEs. Forty-eight respondents (13.3\%) agreed with this statement while 118 educators (32.6\%) disagreed. One hundred seventy-six respondents (48.6\%) indicated they strongly disagreed with this statement.

One hundred fifty-seven educators (43.1\%) strongly agreed with the statement that they were employed during the summer which allowed for SAE supervision while $136(37.4 \%)$ agreed with the statement. Thirty-four respondents (9.3\%) disagreed with the statement. Thirty-seven educators $(10.2 \%)$ strongly disagreed with the statement (see Table 11). 
Table 11

Responses to Selected Statements Concerning Time Issues Associated with SAEs

\begin{tabular}{|c|c|c|c|c|c|c|c|c|}
\hline & \multicolumn{2}{|c|}{ Strongly Disagree } & \multicolumn{2}{|c|}{ Disagree } & \multicolumn{2}{|c|}{ Agree } & \multicolumn{2}{|c|}{ Strongly Agree } \\
\hline & $\mathrm{N}$ & $\%$ & $\mathrm{~N}$ & $\%$ & $\mathrm{~N}$ & $\%$ & $\mathrm{~N}$ & $\%$ \\
\hline $\begin{array}{l}\text { I hold meetings with parents-guardians to explain } \\
\text { the purpose, values, and types of SAEs }\end{array}$ & 34 & 9.3 & 143 & 39.2 & 158 & 43.3 & 30 & 8.2 \\
\hline $\begin{array}{l}\text { I conduct visits to prospective students to explain } \\
\text { the purpose, values, and types of SAEs }\end{array}$ & 14 & 3.9 & 113 & 31.2 & 153 & 42.3 & 82 & 22.7 \\
\hline $\begin{array}{l}\text { Agriculture teachers are responsible for supervision } \\
\text { of students' SAE programs }\end{array}$ & 3 & .8 & 13 & 3.5 & 179 & 48.6 & 173 & 47.0 \\
\hline SAE records are kept on a calendar year basis & 5 & 1.4 & 30 & 8.2 & 158 & 43.3 & 172 & 47.1 \\
\hline $\begin{array}{l}\text { There are not too many students in my program to } \\
\text { supervise everyone that has a SAE }\end{array}$ & 35 & 9.7 & 110 & 30.4 & 182 & 50.3 & 35 & 9.7 \\
\hline $\begin{array}{l}\text { I spend time in the classroom teaching SAE record } \\
\text { keeping }\end{array}$ & 5 & 1.4 & 29 & 8.0 & 170 & 47.0 & 158 & 43.6 \\
\hline I use class time to supervise SAE record keeping & 17 & 4.7 & 62 & 17.0 & 180 & 49.5 & 105 & 28.8 \\
\hline $\begin{array}{l}\text { I am willing to take extra time to make sure } \\
\text { students' SAEs are being properly supervised }\end{array}$ & 2 & .5 & 28 & 7.7 & 212 & 57.9 & 124 & 33.9 \\
\hline I keep SAE visitation records for my program & 9 & 2.5 & 80 & 21.9 & 170 & 46.4 & 107 & 29.2 \\
\hline
\end{tabular}


Table 11 (Continued)

Responses to Selected Statements Concerning Time Issues Associated with SAEs

\begin{tabular}{lcccccccc}
\hline & \multicolumn{2}{c}{ Strongly Disagree } & \multicolumn{2}{c}{ Disagree } & \multicolumn{2}{c}{ Agree } & \multicolumn{2}{c}{ Strongly Agree } \\
\cline { 2 - 9 } & $\mathrm{N}$ & $\%$ & $\mathrm{~N}$ & $\%$ & $\mathrm{~N}$ & $\%$ & $\mathrm{~N}$ & $\%$ \\
\hline $\begin{array}{l}\text { I spend extra time teaching SAE concepts to } \\
\text { freshman }\end{array}$ & 14 & 4.0 & 39 & 11.1 & 142 & 40.5 & 156 & 44.4 \\
$\begin{array}{l}\text { SAEs are worth the extra effort required of the } \\
\text { agricultural educator }\end{array}$ & 2 & .6 & 24 & 6.6 & 183 & 50.4 & 154 & 42.4 \\
$\begin{array}{l}\text { During the school year I am allotted release time } \\
\text { from school to supervise students SAEs }\end{array}$ & 176 & 48.6 & 118 & 32.6 & 48 & 13.3 & 20 & 5.5 \\
$\begin{array}{l}\text { I am employed during the summer which allows for } \\
\text { SAE supervision }\end{array}$ & 37 & 10.2 & 34 & 9.3 & 136 & 37.4 & 157 & 43.1 \\
\hline
\end{tabular}


Composite score averages for statements on the time issues associated with SAEs were calculated. The average for the respondents was $2.96(S D=.48)$ indicating that respondents "agreed." Virginia had the lowest average $(M=2.66)$ and West Virginia had the highest level of agreement $(M=3.12)$ (see Table 12).

Table 12

Composite Score Averages for Selected Statements on Time Issues Associated with SAEs

\begin{tabular}{lcc}
\hline & $M$ & $S D$ \\
\hline Kentucky & 3.01 & .32 \\
Maryland & 2.72 & .51 \\
Ohio & 3.06 & .49 \\
Pennsylvania & 2.81 & .53 \\
Virginia & 2.66 & .49 \\
West Virginia & 3.12 & .43 \\
State not reported & 2.93 & .50 \\
All Participants & 2.96 & .48 \\
\hline
\end{tabular}

\section{Teachers Thoughts and Opinions on SAEs}

The respondents were presented with nine statements relating to their thoughts and opinions on SAEs in agricultural education. One hundred sixty-seven respondents (46.6\%) strongly agreed with the statement that they had a solid understanding of the characteristics of an acceptable SAE. One hundred sixty-six educators (46.4\%) agreed with the statement while $21(5.9 \%)$ disagreed. Four respondents (1.1\%) indicated they strongly disagreed with the statement. 
One hundred ninety-seven respondents (54.7\%) indicated they strongly agreed with the statement that SAEs should be considered one of three essential components of the agricultural education program. Ninety-four educators (26.1\%) indicated they agreed with this statement while 32 (8.9\%) disagreed. Thirty-seven educators (10.3\%) responded that they strongly disagreed with the statement.

Sixty-four educators $(18.1 \%)$ responded that they strongly agreed that they visited every student at least once per year to supervise his/her SAE program. One hundred thirty-three respondents (37.6\%) indicated they agreed with this statement while 131 (37.0\%) disagreed. Twenty-six respondents (7.3\%) indicated they strongly disagreed with the statement.

When presented with the statement that they provided real life examples of SAEs to students in their program, 164 respondents (45.7\%) indicated they strongly agreed with the statement. One hundred eighty-five individuals (51.5\%) indicated they agreed while seven $(1.9 \%)$ disagreed. Three respondents $(0.8 \%)$ indicated they strongly disagreed when presented with this statement.

One hundred ten educators (30.6\%) indicated they strongly agreed they took an active role in helping students design a SAE program. Two hundred twenty-eight educators $(63.5 \%)$ responded they agreed while 20 respondents $(5.6 \%)$ disagreed. One respondent $(0.3 \%)$ indicated he/she strongly disagreed with the statement.

One hundred ninety-eight educators (55.2\%) indicated they strongly agreed that record keeping was a crucial part of a student SAE program. One hundred fifty-three individuals (42.6\%) agreed with the statement while eight (2.2\%) disagreed. 
When presented with the statement that record keeping does not play too large of a role in SAEs, 62 respondents (17.3\%) indicated they strongly agreed while 210 individuals (58.7\%) agreed with the statement. Sixty-three respondents (17.6\%) indicated they disagreed with the statement while 23 respondents (6.4\%) strongly disagreed with the statement.

One hundred eight educators (30.0\%) strongly agreed with the statement that a SAE program should show growth and expansion over the student's career in the agricultural program. Two hundred thirty respondents $(63.9 \%)$ agreed with the statement while 22 respondents $(6.1 \%)$ disagreed with the statement.

Seventy respondents (19.7\%) indicated they strongly agreed with the statement that a student will have earned and invested at least 1,000 dollars, or worked at least 300 hours or a combination thereof in a SAE program at the completion of four years. One hundred sixty-five educators (46.5\%) indicated they agreed while ninety-four respondents (26.5\%) disagreed with the statement. Twenty-six respondents (7.3\%) indicated they strongly disagreed with this statement (see Table 13). 
Table 13

Responses to Selected Statements Concerning Teachers' Thoughts/Opinions on SAEs

\begin{tabular}{|c|c|c|c|c|c|c|c|c|}
\hline & \multicolumn{2}{|c|}{ Strongly Disagree } & \multicolumn{2}{|c|}{ Disagree } & \multicolumn{2}{|c|}{ Agree } & \multicolumn{2}{|c|}{ Strongly Agree } \\
\hline & $\mathrm{N}$ & $\%$ & $\mathrm{~N}$ & $\%$ & $\mathrm{~N}$ & $\%$ & $\mathrm{~N}$ & $\%$ \\
\hline $\begin{array}{l}\text { I have a solid understanding of the characteristics of } \\
\text { an acceptable SAE }\end{array}$ & 4 & 1.1 & 21 & 5.9 & 166 & 46.4 & 167 & 46.6 \\
\hline $\begin{array}{l}\text { SAEs should be considered one of three essential } \\
\text { components of the agricultural education program }\end{array}$ & 37 & 10.3 & 32 & 8.9 & 94 & 26.1 & 197 & 54.7 \\
\hline $\begin{array}{l}\text { I visit every student at least once each year to } \\
\text { supervise his-her SAE program }\end{array}$ & 26 & 7.3 & 131 & 37.0 & 133 & 37.6 & 64 & 18.1 \\
\hline $\begin{array}{l}\text { I provide real life examples of SAEs to students in } \\
\text { my program }\end{array}$ & 3 & .8 & 7 & 1.9 & 185 & 51.5 & 164 & 45.7 \\
\hline $\begin{array}{l}\text { I take an active role in helping students design a } \\
\text { SAE program }\end{array}$ & 1 & .3 & 20 & 5.6 & 228 & 63.5 & 110 & 30.6 \\
\hline $\begin{array}{l}\text { Record keeping is a crucial part of a student SAE } \\
\text { program }\end{array}$ & 0 & .0 & 8 & 2.2 & 153 & 42.6 & 198 & 55.2 \\
\hline $\begin{array}{l}\text { Record keeping does not play too large of a role in } \\
\text { SAEs }\end{array}$ & 23 & 6.4 & 63 & 17.6 & 210 & 58.7 & 62 & 17.3 \\
\hline
\end{tabular}


Table 13 (Continued)

Responses to Selected Statements Concerning Teachers' Thoughts/Opinions on SAEs

\begin{tabular}{|c|c|c|c|c|c|c|c|c|}
\hline & \multicolumn{2}{|c|}{ Strongly Disagree } & \multicolumn{2}{|c|}{ Disagree } & \multicolumn{2}{|c|}{ Agree } & \multicolumn{2}{|c|}{ Strongly Agree } \\
\hline & $\mathrm{N}$ & $\%$ & $\mathrm{~N}$ & $\%$ & $\mathrm{~N}$ & $\%$ & $\mathrm{~N}$ & $\%$ \\
\hline $\begin{array}{l}\text { A SAE program should show growth and expansion } \\
\text { over the student's career in the agriculture program }\end{array}$ & 0 & .0 & 22 & 6.1 & 230 & 63.9 & 108 & 30.0 \\
\hline $\begin{array}{l}\text { A student will have earned and productively } \\
\text { invested at least } \$ 1,000 \text {, or worked at least } 300 \\
\text { hours in excess of scheduled class time, or a } \\
\text { combination thereof, in a supervised agricultural } \\
\text { experience program at the completion of four years }\end{array}$ & 26 & 7.3 & 94 & 26.5 & 165 & 46.5 & 70 & 19.7 \\
\hline
\end{tabular}


Composite score averages for statements on the teachers' thoughts and opinions associated with SAEs were calculated. The average for the group was $3.15(S D=.39)$ indicating that respondents on average "agreed" with the concepts. Virginia had the lowest average $(M=2.91)$ and West Virginia had the highest level of agreement $(M=$ 3.23) (see Table 14).

Table 14

Composite Score Averages for Selected Statements on Teachers’ Thoughts/Opinions Associated with SAEs

\begin{tabular}{llc}
\hline & $M$ & $S D$ \\
\hline Kentucky & 3.17 & .32 \\
Maryland & 3.20 & .31 \\
Ohio & 3.19 & .42 \\
Pennsylvania & 3.09 & .37 \\
Virginia & 2.91 & .39 \\
West Virginia & 3.23 & .38 \\
State not reported & 3.10 & .45 \\
All participants & 3.15 & .39 \\
\hline
\end{tabular}

\section{Concerns with SAE Requirements}

The respondents were presented with a series of seven questions regarding concerns with SAE requirements. Sixty-seven respondents (19.0\%) strongly agreed when presented with the statement that they make sure that all students enrolled in agricultural education have a SAE. One hundred thirty-eight educators (39.1\%) agreed 
while $129(36.5 \%)$ disagreed with the statement. Of the respondents, $19(5.4 \%)$ strongly disagreed with the statement.

Eighty respondents (22.7\%) strongly agreed with the statement that all agricultural education students were required to complete a SAE. One hundred twentyeight educators (36.3\%) agreed while 122 educators (34.6\%) disagreed. Twenty-three respondents (6.5\%) strongly disagreed with the statement.

One hundred eleven respondents (31.4\%) indicated they strongly agreed with the statement that all students with a SAE were keeping a record book. One hundred sixtytwo respondents (45.9\%) agreed with the statement while 73 (20.7\%) disagreed. Seven respondents $(2.0 \%)$ indicated they strongly disagreed with the statement.

When presented with the statement there were not too many students in their program to require SAEs, 68 respondents (19.5\%) strongly agreed. Two hundred three respondents (58.2\%) agreed while $63(18.1 \%)$ disagreed with the statement. Fifteen of the respondents $(4.3 \%)$ indicated they strongly disagreed with this statement.

Seventy-six respondents (21.9\%) indicated they strongly agreed with the statement that all of their "ownership-entrepreneurial" students have approved business agreements. One hundred forty-five respondents (41.8\%) agreed with the statement while $116(33.4 \%)$ disagreed. Ten respondents (2.9\%) strongly disagreed when presented with the statement.

Eighty-four respondents (24.2\%) indicated they strongly agreed with the statement that all of their "placement" students had a training agreement. One hundred fifty-four respondents (44.4\%) agreed while 98 (28.2\%) disagreed with the statement. Eleven of the respondents (3.2\%) indicated they strongly disagreed with the statement. 
Table 15

Responses to Selected Statements Concerning SAE Requirements

\begin{tabular}{|c|c|c|c|c|c|c|c|c|}
\hline & \multicolumn{2}{|c|}{ Strongly disagree } & \multicolumn{2}{|c|}{ Disagree } & \multicolumn{2}{|c|}{ Agree } & \multicolumn{2}{|c|}{ Strongly Agree } \\
\hline & $\mathrm{N}$ & $\%$ & $\mathrm{~N}$ & $\%$ & $\mathrm{~N}$ & $\%$ & $\mathrm{~N}$ & $\%$ \\
\hline $\begin{array}{l}\text { I make sure that all students enrolled in agricultural } \\
\text { education have a SAE }\end{array}$ & 19 & 5.4 & 129 & 36.5 & 138 & 39.1 & 67 & 19.0 \\
\hline $\begin{array}{l}\text { All agricultural education students are required to } \\
\text { complete an SAE }\end{array}$ & 23 & 6.5 & 122 & 34.6 & 128 & 36.3 & 80 & 22.7 \\
\hline All students with a SAE are keeping a record book & 7 & 2.0 & 73 & 20.7 & 162 & 45.9 & 111 & 31.4 \\
\hline $\begin{array}{l}\text { There are not too many students in my program to } \\
\text { require SAEs }\end{array}$ & 15 & 4.3 & 63 & 18.1 & 203 & 58.2 & 68 & 19.5 \\
\hline $\begin{array}{l}\text { All of my "ownership-entrepreneurial" students } \\
\text { have approved business agreements }\end{array}$ & 10 & 2.9 & 116 & 33.4 & 145 & 41.8 & 76 & 21.9 \\
\hline $\begin{array}{l}\text { All of my "placement" students have a training } \\
\text { agreement }\end{array}$ & 11 & 3.2 & 98 & 28.2 & 154 & 44.4 & 84 & 24.2 \\
\hline $\begin{array}{l}\text { Students submit a portfolio to the programs } \\
\text { agricultural education teacher to document } \\
\text { completion of their SAE }\end{array}$ & 31 & 9.0 & 171 & 49.7 & 109 & 31.7 & 33 & 9.6 \\
\hline
\end{tabular}


Thirty-three respondents $(9.6 \%)$ indicated they strongly agreed with the statement that students submit a portfolio to the agricultural education teacher to document completion of their SAE. One hundred nine respondents $(31.7 \%)$ agreed with the statement while $171(49.7 \%)$ disagreed. Thirty-one respondents $(9.0 \%)$ indicated they strongly disagreed with the statement (see Table 15).

Composite score averages for statements on SAE requirements were calculated. The average for the group was $2.80(S D=.57)$ indicating that respondents on average "agreed." Virginia had the lowest average $(M=2.38)$ and Ohio had the highest level of agreement $(M=3.05)$. Ohio was the only state with an average above 3.0 (see Table 16$)$. Table 16 Composite Score Averages for Selected Statements on SAE Requirements

\begin{tabular}{lcc}
\hline & $M$ & $S D$ \\
\hline Kentucky & 2.47 & .47 \\
Maryland & 2.49 & .36 \\
Ohio & 3.05 & .55 \\
Pennsylvania & 2.74 & .58 \\
Virginia & 2.38 & .57 \\
West Virginia & 2.97 & .48 \\
State not reported & 2.82 & .49 \\
All Participants & 2.80 & .57 \\
\hline
\end{tabular}

\section{Student Recognition for SAEs}

Respondents were presented with a series of statements relating to recognition of students for SAEs. Ninety-two respondents (26.9\%) indicated they strongly agreed with 
the statement students were encouraged to participate in SAEs because of the potential recognition. One hundred ninety-two respondents (56.1\%) agreed with the statement while $52(15.2 \%)$ indicated they disagreed with the statement. Six respondents $(1.8 \%)$ indicated they strongly disagreed with this statement.

One hundred forty-four respondents (42.2\%) strongly agreed with the statement that students MUST maintain a SAE program to obtain the Chapter FFA degree. One hundred forty-nine respondents (43.7\%) agreed with the statement while $42(12.3 \%)$ indicated they disagreed. Six respondents $(1.8 \%)$ indicated they strongly disagreed with this statement.

When presented with the statement students SHOULD be required to maintain a SAE program to obtain the chapter FFA degree, 169 respondents $(49.7 \%)$ strongly agreed while 126 respondents $(37.1 \%)$ agreed. Thirty-six respondents $(10.6 \%)$ indicated they disagreed with the statement. Nine respondents $(2.6 \%)$ indicated they strongly disagreed with the statement.

Two hundred twenty-six respondents $(65.9 \%)$ indicated they strongly agreed with the statement that students MUST maintain a SAE program to obtain the State FFA degree. One hundred eleven respondents (32.4\%) indicated agreement with the statement while five respondents $(1.5 \%)$ disagreed. One respondent $(0.3 \%)$ strongly disagreed with the statement.

Two hundred thirteen respondents $(63.0 \%)$ strongly agreed with the statement students SHOULD be required to maintain a SAE program to obtain the State FFA degree. One hundred thirteen respondents (33.4\%) agreed with the statement while ten 
(3.0\%) disagreed. Two respondents $(0.6 \%)$ indicated they strongly disagreed with this statement.

Two hundred thirty-one respondents (68.1\%) indicated they strongly agreed with the statement that students MUST maintain a SAE program to obtain the American FFA degree. One hundred three respondents (30.4\%) agreed with the statement while three (3.0\%) disagreed. Two of the respondents $(0.6 \%)$ indicated they strongly disagreed with the statement.

Two hundred twenty-two respondents (65.1\%) strongly agreed with the statement that students SHOULD be required to maintain a SAE program to obtain the American FFA degree. One hundred eleven respondents (32.6\%) agreed with this statement while six $(1.8 \%)$ indicated they disagreed. Two of the respondents $(0.6 \%)$ strongly disagreed with the statement.

One hundred eighty-eight respondents (55.3\%) indicated they strongly agreed with the statement students MUST maintain a SAE program to be elected to and hold a state FFA office. One hundred twenty-seven respondents (37.4\%) agreed while 23 respondents $(6.8 \%)$ indicated they disagreed with the statement. Two respondents $(0.6 \%)$ indicated they strongly disagreed with the statement.

Two hundred two respondents (59.4\%) strongly agreed when presented with the statement that students SHOULD be required to maintain a SAE program to be elected to and hold a state FFA office. One hundred sixteen respondents (34.1\%) agreed with the statement while fifteen respondents (4.4\%) disagreed. Seven respondents (2.1\%) expressed strong disagreement with the statement. 
When presented with the statement I have not observed student(s) receive a FFA degree (Chapter, State, or American) without having a SAE program, 73 respondents (21.7\%) expressed strong agreement. One hundred sixteen (34.1\%) agreed with the statement while 15 (4.4\%) indicated they disagreed. Twenty-five respondents (7.4\%) indicated they strongly disagreed with the statement.

Eighty-nine respondents (27.1\%) strongly agreed with the statement that they have not observed student(s) elected to a State FFA office without having a SAE program. One hundred ninety-three respondents (58.7\%) expressed agreement with the statement while $34(10.3 \%)$ disagreed. Thirteen respondents (4.0\%) strongly disagreed with the statement (see Table 17). 
Table 17

Responses to Selected Statements Concerning Student Recognition for SAEs

\begin{tabular}{|c|c|c|c|c|c|c|c|c|}
\hline & \multicolumn{2}{|c|}{ Strongly Disagree } & \multicolumn{2}{|c|}{ Disagree } & \multicolumn{2}{|c|}{ Agree } & \multicolumn{2}{|c|}{ Strongly Agree } \\
\hline & $\mathrm{N}$ & $\%$ & $\mathrm{~N}$ & $\%$ & $\mathrm{~N}$ & $\%$ & $\mathrm{~N}$ & $\%$ \\
\hline $\begin{array}{l}\text { Students are encouraged to participate in SAEs } \\
\text { because of the potential recognition a student can } \\
\text { earn }\end{array}$ & 6 & 1.8 & 52 & 15.2 & 192 & 56.1 & 92 & 26.9 \\
\hline $\begin{array}{l}\text { Students must maintain a SAE program to obtain } \\
\text { the Chapter FFA degree }\end{array}$ & 6 & 1.8 & 42 & 12.3 & 149 & 43.7 & 144 & 42.2 \\
\hline $\begin{array}{l}\text { Students should be required to maintain a SAE } \\
\text { program to obtain the Chapter FFA degree }\end{array}$ & 9 & 2.6 & 36 & 10.6 & 126 & 37.1 & 169 & 49.7 \\
\hline $\begin{array}{l}\text { Students must maintain a SAE program to obtain } \\
\text { the State FFA degree }\end{array}$ & 1 & .3 & 5 & 1.5 & 111 & 32.4 & 226 & 65.9 \\
\hline $\begin{array}{l}\text { Students should be required to maintain a SAE } \\
\text { program to obtain the State FFA degree }\end{array}$ & 2 & .6 & 10 & 3.0 & 113 & 33.4 & 213 & 63.0 \\
\hline $\begin{array}{l}\text { Students must maintain a SAE program to obtain } \\
\text { the American FFA degree }\end{array}$ & 2 & .6 & 3 & .9 & 103 & 30.4 & 231 & 68.1 \\
\hline $\begin{array}{l}\text { Students should be required to maintain a SAE } \\
\text { program to obtain the American FFA degree }\end{array}$ & 2 & .6 & 6 & 1.8 & 111 & 32.6 & 222 & 65.1 \\
\hline
\end{tabular}


Table 17 (Continued)

Responses to Selected Statements Concerning Student Recognition for SAEs

\begin{tabular}{|c|c|c|c|c|c|c|c|c|}
\hline & \multicolumn{2}{|c|}{ Strongly Disagree } & \multicolumn{2}{|c|}{ Disagree } & \multicolumn{2}{|c|}{ Agree } & \multicolumn{2}{|c|}{ Strongly Agree } \\
\hline & $\mathrm{N}$ & $\%$ & $\mathrm{~N}$ & $\%$ & $\mathrm{~N}$ & $\%$ & $\mathrm{~N}$ & $\%$ \\
\hline $\begin{array}{l}\text { Students must maintain a SAE program to be } \\
\text { elected to and hold a state FFA office }\end{array}$ & 2 & .6 & 23 & 6.8 & 127 & 37.4 & 188 & 55.3 \\
\hline $\begin{array}{l}\text { Students should be required to maintain a SAE } \\
\text { program to be elected to and hold a state FFA office }\end{array}$ & 7 & 2.1 & 15 & 4.4 & 116 & 34.1 & 202 & 59.4 \\
\hline $\begin{array}{l}\text { I have not observed student(s) receive a FFA degree } \\
\text { (Chapter, State, American) without having a SAE } \\
\text { program }\end{array}$ & 25 & 7.4 & 65 & 19.3 & 174 & 51.6 & 73 & 21.7 \\
\hline $\begin{array}{l}\text { I have not observed student(s) elected to a State } \\
\text { FFA office without having a SAE program }\end{array}$ & 13 & 4.0 & 34 & 10.3 & 193 & 58.7 & 89 & 27.1 \\
\hline
\end{tabular}


Composite score averages for statements on student recognition issues with SAEs were calculated. The average for the group was $3.37(S D=.46)$ indicating that respondents on average "agreed." Virginia $(M=3.23)$ and Maryland $(M=3.24)$ had the lowest averages. West Virginia had the highest level of agreement $(M=3.60)$ (see Table $18)$.

Table 18

Composite Score Averages for Selected Statements on student Recognition Issues with SAEs

\begin{tabular}{lcc}
\hline & $M$ & $S D$ \\
\hline Kentucky & 3.34 & .39 \\
Maryland & 3.24 & .38 \\
Ohio & 3.38 & .49 \\
Pennsylvania & 3.34 & .44 \\
Virginia & 3.23 & .46 \\
West Virginia & 3.60 & .38 \\
State not reported & 3.29 & .59 \\
All Participants & 3.37 & .46 \\
\hline
\end{tabular}

\section{Teacher Competence with SAEs}

Respondents were presented with seven statements regarding teacher competence with SAEs and asked to indicate their level of agreement. One hundred fifty-seven respondents $(47.0 \%)$ strongly agreed that they were familiar enough with concepts of SAEs to feel comfortable teaching the topic. One hundred fifty-two respondents $(45.5 \%)$ 
agreed with the statement while 18 (5.4\%) disagreed. Seven respondents (2.1\%) strongly disagreed with this statement.

When presented with the statement that they were familiar enough with SAE record keeping to feel comfortable teaching record keeping practices 140 respondents (41.4\%) strongly agreed. One hundred sixty-three respondents (48.2\%) expressed they agreed with the statement while $26(7.7 \%)$ disagreed. Nine respondents $(2.7 \%)$ strongly disagreed with the statement.

Ninety-two respondents (27.3\%) indicated they strongly agreed with the statement that they had received training on how to supervise SAEs in their teacher preparation program (classes, workshops, etc.). One hundred thirty-nine individuals (41.2\%) agreed with the statement while $74(22.0 \%)$ disagreed. Thirty-two respondents $(9.5 \%)$ strongly disagreed with the statement.

Fifty-five respondents (16.3\%) indicated they strongly agreed with the statement that they were familiar with newer types of SAEs such as the research SAE. One hundred forty individuals (41.5\%) agreed with the statement while 121 (35.9\%) expressed disagreement with the statement. Twenty-one respondents (6.2\%) strongly disagreed with the statement.

Fifty-one respondents (15.1\%) strongly agreed with the statement that they were familiar with newer types of SAEs such as the exploratory SAE while 133 respondents (39.5\%) indicated they agreed. One hundred twenty-six respondents (37.4\%) strongly disagreed with the statement. The remaining 27 respondents $(8.0 \%)$ indicated they strongly disagreed with this statement. 
One hundred ten respondents $(32.7 \%)$ expressed they strongly agreed with the statement that they have an adequate understanding of SAEs. One hundred ninety-four respondents (57.7\%) agreed with the statement while $25(7.4 \%)$ disagreed. Seven individuals $(2.1 \%)$ expressed strong disagreement with the statement.

When respondents were presented with the statement that they regularly refer to SAEs during class period instruction, 97 respondents (28.8\%) indicated they strongly agreed. One hundred sixty-one respondents (47.8\%) agreed with the statement while 70 $(20.8 \%)$ disagreed. While nine respondents $(2.7 \%)$ indicated they strongly disagreed with the statement (see Table 19). 
Table 19

Responses to Selected Statements Concerning Teacher Competence with SAEs

\begin{tabular}{|c|c|c|c|c|c|c|c|c|}
\hline & \multicolumn{2}{|c|}{ Strongly Disagree } & \multicolumn{2}{|c|}{ Disagree } & \multicolumn{2}{|c|}{ Agree } & \multicolumn{2}{|c|}{ Strongly Agree } \\
\hline & $\mathrm{N}$ & $\%$ & $\mathrm{~N}$ & $\%$ & $\mathrm{~N}$ & $\%$ & $\mathrm{~N}$ & $\%$ \\
\hline $\begin{array}{l}\text { I am familiar enough with concepts of SAEs to feel } \\
\text { comfortable teaching the topic }\end{array}$ & 7 & 2.1 & 18 & 5.4 & 152 & 45.5 & 157 & 47.0 \\
\hline $\begin{array}{l}\text { I am familiar enough with SAE record keeping to } \\
\text { feel comfortable teaching record keeping practices }\end{array}$ & 9 & 2.7 & 26 & 7.7 & 163 & 48.2 & 140 & 41.4 \\
\hline $\begin{array}{l}\text { I received training on how to supervise SAEs in } \\
\text { my teacher preparation program (classes, } \\
\text { workshops, etc.) }\end{array}$ & 32 & 9.5 & 74 & 22.0 & 139 & 41.2 & 92 & 27.3 \\
\hline $\begin{array}{l}\text { I am familiar with newer types of SAEs such as the } \\
\text { research SAE }\end{array}$ & 21 & 6.2 & 121 & 35.9 & 140 & 41.5 & 55 & 16.3 \\
\hline $\begin{array}{l}\text { I am familiar with newer types of SAEs such as the } \\
\text { exploratory SAE }\end{array}$ & 27 & 8.0 & 126 & 37.4 & 133 & 39.5 & 51 & 15.1 \\
\hline I have an adequate understanding of SAEs & 7 & 2.1 & 25 & 7.4 & 194 & 57.7 & 110 & 32.7 \\
\hline $\begin{array}{l}\text { I regularly refer to SAEs during class period } \\
\text { instruction }\end{array}$ & 9 & 2.7 & 70 & 20.8 & 161 & 47.8 & 97 & 28.8 \\
\hline
\end{tabular}


Composite score averages for statements on teacher competence with SAEs were calculated. The average for the group was $3.01(S D=.55)$ indicating that respondents on average "agreed." Virginia had the lowest average $(M=2.81)$ and West Virginia had the highest level of agreement $(M=3.13)$ (see Table 20).

Table 20

Composite Score Averages for Selected Statements on Teacher Competence with SAEs

\begin{tabular}{lcc}
\hline & $M$ & $S D$ \\
\hline Kentucky & 3.00 & .56 \\
Maryland & 3.05 & .77 \\
Ohio & 2.99 & .53 \\
Pennsylvania & 3.04 & .54 \\
Virginia & 2.81 & .60 \\
West Virginia & 3.13 & .45 \\
State not reported & 2.93 & .64 \\
All Participants & 3.01 & .55 \\
\hline
\end{tabular}

\section{Support Issues Associated with SAEs}

Respondents were presented with a series of ten questions regarding support issues associated with SAEs. Ninety-seven respondents (29.1\%) expressed they strongly agreed with the statement that they were reimbursed for travel to complete SAE visitations. One hundred forty-four respondents $(43.2 \%)$ indicated they agreed with the statement while 51 (15.3\%) disagreed. Forty-one respondents (12.3\%) strongly disagreed with the statement. 
Thirty-eight respondents (11.4\%) strongly agreed with the statement that they kept a list of employers who were willing to serve as a training center for students SAEs. One hundred forty-eight respondents (44.6\%) agreed with the statement while one hundred twenty-two (36.7\%) disagreed. Twenty-four individuals (7.2\%) responded they strongly disagreed with the statement.

Thirty-six respondents (10.9\%) indicated they strongly agreed with the statement that they worked with their advisory committee to develop a list of prospective training center employers for placement SAEs. One hundred twenty-four respondents (37.5\%) agreed with the statement while 144 (43.5\%) disagreed. Twenty-seven individuals $(8.2 \%)$ expresses they strongly disagreed with this statement.

When presented with the statement that they worked with their administration to develop a list of prospective training center employers for placement SAEs, 20 respondents (6.1\%) strongly agreed. Eighty-three respondents (25.2\%) agreed with the statement while $187(56.7 \%)$ disagreed. Forty respondents (12.1\%) indicated they strongly disagreed with the statement.

Twenty-one respondents (6.4\%) strongly agreed when presented with the statement that they interview prospective cooperating employers to determine if the employment situation was suitable and the employer was interested in establishing a training center for SAE placement. One hundred eight respondents (33.1\%) agreed with the statement. One hundred sixty-six respondents (50.9\%) disagreed with the statement while thirty-one (9.5\%) expressed they strongly disagreed.

One hundred seventy-seven respondents (53.5\%) expressed they strongly agreed with the statement SAEs were an educational tool that leads to life-long learning. One 
hundred forty-four respondents (43.5\%) agreed with the statement, while eight $(2.4 \%)$ disagreed. Two respondents $(0.6 \%)$ expressed they strongly disagreed with the statement.

Twenty-four respondents $(7.3 \%)$ indicated they strongly agreed that most students have the resources to have an adequate SAE. One hundred ninety respondents $(57.4 \%)$ agreed with the statement, while $95(28.7 \%)$ disagreed. Twenty-two of the respondents $(6.6 \%)$ indicated they strongly disagreed with the statement.

When presented with the statement most parents feel that SAEs are a valuable learning experience, 19 respondents (5.8\%) strongly agreed. Two hundred eleven respondents $(64.7 \%)$ expressed agreement, while $81(24.8 \%)$ indicated they disagreed with the statement. Fifteen respondents (4.6\%) expressed they strongly disagreed with the statement.

Thirty-three respondents $(10.0 \%)$ strongly agreed with the statement that SAEs provide students with adequate earnings for the amount of work required. Two hundred sixteen respondents $(65.7 \%)$ indicated they agreed, while $74(22.5 \%)$ disagreed with the statement. Six of the respondents $(1.8 \%)$ indicated they strongly disagreed with the statement.

Thirty-two respondents (9.7\%) strongly agreed with the statement that their students have a good understanding of SAE concepts. Two hundred twenty-nine respondents (69.4\%) agreed with the statement while $63(19.1 \%)$ indicated they disagreed. Six of the respondents $(1.8 \%)$ expressed they strongly disagreed with this statement (see Table 21). 
Table 21

Responses to Selected Statements Concerning Support Issues Associated with SAEs

\begin{tabular}{|c|c|c|c|c|c|c|c|c|}
\hline & \multicolumn{2}{|c|}{ Strongly Disagree } & \multicolumn{2}{|c|}{ Disagree } & \multicolumn{2}{|c|}{ Agree } & \multicolumn{2}{|c|}{ Strongly Agree } \\
\hline & $\mathrm{N}$ & $\%$ & $\mathrm{~N}$ & $\%$ & $\mathrm{~N}$ & $\%$ & $\mathrm{~N}$ & $\%$ \\
\hline $\begin{array}{l}\text { I am reimbursed for travel to complete SAE } \\
\text { visitations }\end{array}$ & 41 & 12.3 & 51 & 15.3 & 144 & 43.2 & 97 & 29.1 \\
\hline $\begin{array}{l}\text { I keep a list of employers who are willing to serve } \\
\text { as a training center for students' SAEs }\end{array}$ & 24 & 7.2 & 122 & 36.7 & 148 & 44.6 & 38 & 11.4 \\
\hline $\begin{array}{l}\text { I work with my advisory committee to develop a list } \\
\text { of prospective training center employers for } \\
\text { placement SAEs }\end{array}$ & 27 & 8.2 & 144 & 43.5 & 124 & 37.5 & 36 & 10.9 \\
\hline $\begin{array}{l}\text { I work with my administration to develop a list of } \\
\text { prospective training center employers for placement } \\
\text { SAEs }\end{array}$ & 40 & 12.1 & 187 & 56.7 & 83 & 25.2 & 20 & 6.1 \\
\hline $\begin{array}{l}\text { I interview prospective cooperating employers to } \\
\text { determine if the employment situation is suitable } \\
\text { and the employer is interested in establishing a } \\
\text { training center for SAE placement }\end{array}$ & 31 & 9.5 & 166 & 50.9 & 108 & 33.1 & 21 & 6.4 \\
\hline $\begin{array}{l}\text { SAEs are an educational tool that leads to life-long } \\
\text { learning }\end{array}$ & 2 & .6 & 8 & 2.4 & 144 & 43.5 & 177 & 53.5 \\
\hline
\end{tabular}


Table 21 (Continued)

Responses to Selected Statements Concerning Support Issues Associated with SAEs

\begin{tabular}{|c|c|c|c|c|c|c|c|c|}
\hline & \multicolumn{2}{|c|}{ Strongly Disagree } & \multicolumn{2}{|c|}{ Disagree } & \multicolumn{2}{|c|}{ Agree } & \multicolumn{2}{|c|}{ Strongly Agree } \\
\hline & $\mathrm{N}$ & $\%$ & $\mathrm{~N}$ & $\%$ & $\mathrm{~N}$ & $\%$ & $\mathrm{~N}$ & $\%$ \\
\hline $\begin{array}{l}\text { Most students have the resources to have an } \\
\text { adequate SAE }\end{array}$ & 22 & 6.6 & 95 & 28.7 & 190 & 57.4 & 24 & 7.3 \\
\hline $\begin{array}{l}\text { Most parents feel that SAEs are a valuable learning } \\
\text { tool }\end{array}$ & 15 & 4.6 & 81 & 24.8 & 211 & 64.7 & 19 & 5.8 \\
\hline $\begin{array}{l}\text { SAEs provide students with adequate earnings for } \\
\text { the amount of work required }\end{array}$ & 6 & 1.8 & 74 & 22.5 & 216 & 65.7 & 33 & 10.0 \\
\hline $\begin{array}{l}\text { My students have a good understanding of SAEs } \\
\text { concepts }\end{array}$ & 6 & 1.8 & 63 & 19.1 & 229 & 69.4 & 32 & 9.7 \\
\hline
\end{tabular}


Composite score averages for statements associated with support of SAEs were calculated. The average for the group was $2.72(S D=.43)$. Virginia had the lowest average $(M=2.40)$. Individuals who did not report their state had the highest average $(M$ $=2.84)$ followed by West Virginia $(M=2.83)$ (see Table 22$)$.

Table 22

Composite Score Averages for Selected Statements Associated with Support of SAEs

\begin{tabular}{lcc}
\hline & $M$ & $S D$ \\
\hline Kentucky & 2.74 & .42 \\
Maryland & 2.81 & .44 \\
Ohio & 2.75 & .41 \\
Pennsylvania & 2.60 & .38 \\
Virginia & 2.40 & .57 \\
West Virginia & 2.83 & .37 \\
State not reported & 2.84 & .49 \\
All Participants & 2.72 & .43 \\
\hline
\end{tabular}

\section{Program Issues Associated with SAEs}

Respondents were presented with four statements regarding their programs issues associated with SAEs. One hundred fifty-four respondents (47.2\%) expressed they strongly agreed with the statement that agricultural programs benefit from the SAE component. One hundred fifty-nine respondents (48.8\%) agreed with the statement, while $11(3.4 \%)$ expressed they disagreed with the statement. Two respondents $(0.6 \%)$ expressed they strongly disagreed with the statement. 
One hundred eighty-one respondents (55.4\%) strongly agreed that when presenting with the statement SAE, FFA, and classroom experiences must all work together for a quality agricultural education program. One hundred twenty-two respondents (37.3\%) agreed, while $20(6.1 \%)$ disagreed with the statement. Four respondents (1.2\%) strongly disagreed with the statement.

When presented with the statement that their agricultural education program receives more recognition from SAE programs than FFA activities, three respondents $(0.9 \%)$ strongly agreed. Sixty-two respondents $(19.0 \%)$ agreed with the statement, while 148 respondents $(45.4 \%)$ disagreed. One hundred thirteen respondents $(34.7 \%)$ expressed they strongly disagreed with the statement.

Seven respondents $(2.1 \%)$ expressed they strongly agreed that they focus more on SAEs than FFA activities within their program. One hundred sixteen respondents (35.4\%) agreed with the statement while 148 respondents $(45.1 \%)$ indicated they disagreed. Fifty-seven respondents (17.4\%) strongly disagreed with this statement (see Table 23). 
Table 23

Responses to Selected Statements Concerning Program Issues Associated with SAEs

\begin{tabular}{|c|c|c|c|c|c|c|c|c|}
\hline & \multicolumn{2}{|c|}{ Strongly Disagree } & \multicolumn{2}{|c|}{ Disagree } & \multicolumn{2}{|c|}{ Agree } & \multicolumn{2}{|c|}{ Strongly Agree } \\
\hline & $\mathrm{N}$ & $\%$ & $\mathrm{~N}$ & $\%$ & $\mathrm{~N}$ & $\%$ & $\mathrm{~N}$ & $\%$ \\
\hline $\begin{array}{l}\text { The agricultural program benefits from the SAE } \\
\text { component }\end{array}$ & 2 & .6 & 11 & 3.4 & 159 & 48.8 & 154 & 47.2 \\
\hline $\begin{array}{l}\text { SAE, FFA, and classroom experiences must all } \\
\text { work together for a quality agricultural education } \\
\text { program }\end{array}$ & 4 & 1.2 & 20 & 6.1 & 122 & 37.3 & 181 & 55.4 \\
\hline $\begin{array}{l}\text { My agricultural education program receives more } \\
\text { recognition from SAE programs than FFA } \\
\text { Activities }\end{array}$ & 113 & 34.7 & 148 & 45.4 & 62 & 19.0 & 3 & .9 \\
\hline $\begin{array}{l}\text { I focus more on SAEs than FFA activities within } \\
\text { my program }\end{array}$ & 57 & 17.4 & 148 & 45.1 & 116 & 35.4 & 7 & 2.1 \\
\hline
\end{tabular}


Composite score averages for statements on program issues with SAEs were calculated. The average for the group was $2.74(S D=.50)$. Virginia had the lowest average $(M=2.29)$ followed by Pennsylvania $(M=2.59)$. West Virginia had the highest level of agreement $(M=2.90)$ (see Table 24).

Table 24

Composite Score Averages for Selected Statements on Program Issues Associated with SAES

\begin{tabular}{lcc}
\hline & $M$ & $S D$ \\
\hline Kentucky & 2.73 & .50 \\
Maryland & 2.65 & .44 \\
Ohio & 2.85 & .46 \\
Pennsylvania & 2.59 & .51 \\
Virginia & 2.29 & .55 \\
West Virginia & 2.90 & .43 \\
State not reported & 2.74 & .54 \\
All Participants & 2.74 & .50 \\
\hline
\end{tabular}

\section{Program Statistics for Agricultural Education Programs}

Respondents were presented with a series of open ended questions asking them to report statistics of their program. The data provided by the respondents were then used to calculate a percentage for each question. When calculated the percentage of students who had an active SAE the average percentage was $63.92 \%(S D=33.32)$. Virginia (38.94\%) and Maryland (43.93\%) had the lowest percentage of students with an active SAE. Ohio (78.42\%) had the highest percentage with West Virginia (69.97\%) second. 
The percentage of students earning a chapter degree was calculated. The results showed that $18.59 \%$ of students in the agricultural education programs represented in the study earned their Chapter FFA degree. Pennsylvania (12.70\%) recorded the lowest percentage while Virginia (12.81\%) was the second lowest. Ohio (25.88\%) had the highest percentage of students earning a Chapter FFA degree while West Virginia (15.68\%) had the second highest percentage.

Calculations were performed to determine the percentage of students earning their State FFA degree. The results indicated that for the teachers involved in the study, 3.62\% of students in agricultural education earned their State FFA degree. Of the states involved, Virginia (2.42\%) had the lowest percentage of students earning a state degree. Maryland (4.33\%) and Ohio (4.10\%) reported the highest percentage of students earning their State FFA degree.

When examining the percentage of students who received their American FFA degree, $1.14 \%$ of agricultural education students earned their American FFA degree. West Virginia (0.49\%) had the lowest percentage with Maryland (0.55\%) the second lowest. Ohio (1.73\%) had the highest percentage of students who received an American FFA degree.

Respondents were asked to provide the number of students filling out state proficiency award applications. In the programs represented by the respondents, $2.55 \%$ of students filled out state proficiency award applications. Pennsylvania (0.78\%) and Maryland $(0.98 \%)$ had the lowest percentage of student filling out proficiency awards applications. Kentucky (4.61\%) and Ohio (3.19\%) had the highest percentage of students applying for state proficiency awards (see Table 25). 
Table 25

Self-Reported Program Statistics for Agricultural Education Programs

\begin{tabular}{|c|c|c|c|c|c|c|}
\hline & & & & Percent & & \\
\hline & & SAE & $\begin{array}{c}\text { Chapter FFA } \\
\text { Degree }\end{array}$ & $\begin{array}{l}\text { State FFA } \\
\text { Degree }\end{array}$ & $\begin{array}{l}\text { American } \\
\text { FFA Degree }\end{array}$ & $\begin{array}{c}\text { State } \\
\text { Proficiency } \\
\text { Award } \\
\text { Applications }\end{array}$ \\
\hline \multirow[t]{2}{*}{ Kentucky } & $M$ & 60.09 & 15.34 & 3.76 & .84 & 4.61 \\
\hline & $S D$ & 30.74 & 11.93 & 7.04 & 1.16 & 6.05 \\
\hline \multirow[t]{2}{*}{ Maryland } & $M$ & 43.93 & 17.06 & 4.33 & .55 & .98 \\
\hline & $S D$ & 32.15 & 8.50 & 3.88 & 1.13 & 1.62 \\
\hline \multirow[t]{2}{*}{ Ohio } & $M$ & 78.42 & 25.88 & 4.10 & 1.73 & 3.19 \\
\hline & $S D$ & 29.70 & 14.06 & 3.71 & 2.11 & 6.45 \\
\hline \multirow[t]{2}{*}{ Pennsylvania } & $M$ & 48.23 & 12.70 & 2.89 & 1.00 & .78 \\
\hline & $S D$ & 32.68 & 11.91 & 2.97 & 1.97 & 1.70 \\
\hline \multirow[t]{2}{*}{ Virginia } & $M$ & 38.94 & 12.81 & 2.42 & .86 & 1.04 \\
\hline & $S D$ & 33.73 & 9.40 & 2.46 & 1.41 & 1.89 \\
\hline \multirow[t]{2}{*}{ West Virginia } & $M$ & 69.97 & 15.68 & 3.46 & .49 & 1.79 \\
\hline & $S D$ & 29.14 & 10.47 & 3.42 & .94 & 3.14 \\
\hline \multirow[t]{2}{*}{$\begin{array}{l}\text { State not } \\
\text { reported }\end{array}$} & $M$ & 65.42 & 14.37 & 3.62 & 1.67 & 1.47 \\
\hline & $S D$ & 32.71 & 7.78 & 3.04 & 1.60 & 1.58 \\
\hline \multirow[t]{2}{*}{ Total } & $M$ & 63.92 & 18.59 & 3.62 & 1.14 & 2.55 \\
\hline & $S D$ & 33.32 & 13.39 & 4.36 & 1.76 & 5.06 \\
\hline
\end{tabular}




\section{Numbers for Agricultural Education Program}

Respondents were asked a series of open ended questions regarding the current numbers in their agricultural education program. It was requested that responses be given in number form and the percentages were calculated. Respondents were asked to indicate the number of students they had participating in an exploratory SAE. The group average revealed that $21.82 \%$ of students in agricultural education had an exploratory SAE. The respondents who did not report their state (9.27\%) and West Virginia (10.70\%) had the lowest percentage of exploratory SAEs. Virginia (44.31\%) had the highest percentage of exploratory SAEs followed by Kentucky (32.96\%).

Calculations of research SAEs revealed that an average of $5.91 \%$ of students had a research SAE. Maryland (3.30\%) had the lowest percentage of research SAEs followed by Pennsylvania (3.59\%). Virginia (13.14\%) had that highest percentage of students with research SAEs, with Ohio $(7.82 \%)$ the second highest.

Respondents were asked to give the number of students participating in an ownership SAE, the numbers for each state were averaged and the percentage was calculated. The average number of students with ownership SAEs was $46.74 \%$. Virginia respondents $(27.13 \%)$ had the lowest percentage of ownership SAEs. West Virginia $(60.85 \%)$ and Maryland (52.96\%) had the highest percentage of ownership SAEs.

Calculations with placement SAEs were completed, an average of $44.03 \%$ of the students had a placement SAE. States with the lowest percentage of students with a placement SAE were Pennsylvania (32.02\%) and Maryland (33.45\%). Teachers who did not report their state (69.01\%) and Kentucky (57.97\%) had the highest percentage of students using placement as a SAE (see Table 26). 
Table 26

Self-Reported SAE Percentages for Agricultural Education Programs

\begin{tabular}{|c|c|c|c|c|c|}
\hline & & \multicolumn{4}{|c|}{ Percent SAEs } \\
\hline & & Exploratory & Research & Ownership & Placement \\
\hline \multirow[t]{2}{*}{ Kentucky } & $M$ & 32.96 & 4.08 & 38.31 & 57.97 \\
\hline & $S D$ & 86.20 & 10.40 & 38.75 & 46.07 \\
\hline \multirow[t]{2}{*}{ Maryland } & $M$ & 22.41 & 3.30 & 52.96 & 33.45 \\
\hline & $S D$ & 28.14 & 5.29 & 26.78 & 22.93 \\
\hline \multirow[t]{2}{*}{ Ohio } & $M$ & 13.23 & 7.82 & 47.96 & 46.71 \\
\hline & $S D$ & 27.41 & 17.91 & 26.89 & 27.20 \\
\hline \multirow[t]{2}{*}{ Pennsylvania } & $M$ & 30.30 & 3.59 & 44.82 & 32.02 \\
\hline & $S D$ & 34.11 & 9.69 & 30.03 & 24.95 \\
\hline \multirow[t]{2}{*}{ Virginia } & $M$ & 44.31 & 13.14 & 27.13 & 46.44 \\
\hline & $S D$ & 41.63 & 25.73 & 34.41 & 44.28 \\
\hline \multirow[t]{2}{*}{ West Virginia } & $M$ & 10.70 & 3.82 & 60.85 & 33.80 \\
\hline & $S D$ & 26.02 & 8.71 & 26.87 & 23.79 \\
\hline \multirow[t]{2}{*}{$\begin{array}{l}\text { State not } \\
\text { reported }\end{array}$} & $M$ & 9.27 & 6.40 & 40.37 & 69.01 \\
\hline & $S D$ & 13.70 & 8.54 & 30.97 & 46.10 \\
\hline \multirow[t]{2}{*}{ Total } & $M$ & 21.82 & 5.91 & 46.74 & 44.03 \\
\hline & $S D$ & 47.52 & 14.35 & 31.20 & 33.16 \\
\hline
\end{tabular}

\section{SAE Numbers}

Respondents were presented with the statement "A desired SAE is one in which a student will have earned and productively invested at least $\$$ , or worked at least 
hours in excess of scheduled class time, or a combination thereof, in a supervised agricultural experience program at the completion of four years." The average was taken for each state and the total states combined. The average for all respondents was \$1214.24 while Virginia (\$635.00) had the lowest dollar value. West Virginia (\$1714.71) expressed the highest dollar value for a desired SAE.

The average number of hours for an SAE was 372.05 hours. Virginia (185.45 hrs) had the lowest number of desired hours for a SAE followed by the unreported states (216.67 hrs). Ohio (427.72 hrs) and Kentucky (413.93 hrs) indicated the highest number of hours for a desired SAE (see Table 27).

Respondents were asked open ended questions about time in hours devoted to SAE instruction. When asked to indicate the number of hours devoted to SAEs in their introductory course the average response was 18.16 hours. Respondents who did not report their state (58.75) had the highest amount of time devoted to teaching SAE in introductory courses followed by teachers in Kentucky (25.21). Maryland respondents (6.92) expressed the lowest amount of hours devoted to SAE in their introductory course.

Respondents were asked how many hours they devote to SAE instruction in all other program courses. The average for the states involved was 11.13 hours devoted to SAEs. Maryland (7.73) and Ohio (8.29) had the lowest number of hours devoted to teaching SAEs in program courses. Virginia (32.89) had the highest average of hours devoted to teaching SAEs in program courses followed by respondents who did not report their state (22.80) (see Table 27). 
Table 27

Self-Reported SAE Numbers for Agricultural Education Programs

\begin{tabular}{|c|c|c|c|c|c|}
\hline & & \multicolumn{2}{|c|}{ Desired SAE Scope } & \multicolumn{2}{|c|}{$\begin{array}{l}\text { Time Devoted to SAE } \\
\text { Instruction (Hours) }\end{array}$} \\
\hline & & Dollars & Hours & $\begin{array}{l}\text { Introductory } \\
\text { course }\end{array}$ & $\begin{array}{c}\text { All other } \\
\text { program courses }\end{array}$ \\
\hline \multirow[t]{2}{*}{ Kentucky } & $M$ & 1507.24 & 413.93 & 25.21 & 9.54 \\
\hline & $S D$ & 2133.79 & 525.67 & 66.88 & 12.14 \\
\hline \multirow[t]{2}{*}{ Maryland } & $M$ & 1111.11 & 311.80 & 6.92 & 7.73 \\
\hline & $S D$ & 885.22 & 434.29 & 6.11 & 8.62 \\
\hline \multirow[t]{2}{*}{ Ohio } & $M$ & 1237.88 & 427.72 & 15.06 & 8.29 \\
\hline & $S D$ & 1311.40 & 410.30 & 15.79 & 8.23 \\
\hline \multirow[t]{2}{*}{ Pennsylvania } & $M$ & 657.14 & 287.22 & 15.35 & 10.51 \\
\hline & $S D$ & 358.62 & 230.16 & 14.52 & 21.71 \\
\hline \multirow[t]{2}{*}{ Virginia } & $M$ & 635.00 & 185.45 & 18.47 & 32.89 \\
\hline & $S D$ & 413.69 & 114.92 & 50.43 & 105.86 \\
\hline \multirow[t]{2}{*}{ West Virginia } & $M$ & 1714.71 & 407.09 & 18.65 & 12.97 \\
\hline & $S D$ & 2607.99 & 330.48 & 17.03 & 13.94 \\
\hline \multirow[t]{2}{*}{$\begin{array}{l}\text { State not } \\
\text { reported }\end{array}$} & $M$ & 666.67 & 216.67 & 58.75 & 22.80 \\
\hline & $S D$ & 577.35 & 144.34 & 81.28 & 43.18 \\
\hline \multirow[t]{2}{*}{ Total } & $M$ & 1214.24 & 372.05 & 18.16 & 11.13 \\
\hline & $S D$ & 1670.05 & 388.66 & 36.08 & 27.42 \\
\hline
\end{tabular}




\section{CHAPTER V}

\section{Summary, Conclusions, and Recommendations}

\section{Problem Statement}

The purpose of this study was to determine the emphasis and importance agricultural education teachers place on supervised agricultural experiences in agricultural education programs. It was also designed to look at reasons an educator does or does not encourage students to take part in SAEs. This study will be helpful in providing information to agricultural teachers, state supervisors and students.

The objectives of the study are reflected in the following research questions:

1. What were the views of agricultural educators about SAEs?

2. What SAE opportunities existed for students?

3. How much emphasis was placed on teaching SAEs in the classroom?

4. Were SAES used as a part of students' final grades?

5. What was the role of parental support in the student having a SAE?

6. Were record keeping skills taught as a part of SAEs?

7. What were teachers' opinions on SAEs being essential to earn degrees and awards in the FFA?

\section{Summary}

The accessible population consisted of 1,500 current agricultural education teachers in Kentucky, Maryland, Ohio, Pennsylvania, Virginia and West Virginia. Three hundred ninety-one questionnaires $(26.0 \%)$ were completed. Of the respondents 63 (16.1\%) were from Kentucky, 17 (4.3\%) indicated they taught in Maryland while 106 $(27.1 \%)$ were from Ohio. Fifty-eight respondents $(14.8 \%)$ taught in the state of 
Pennsylvania, 18 respondents (4.6\%) indicated that they taught in Virginia while 47 respondents (12.0\%) taught in West Virginia. Eighty-two respondents (21.0\%) did not indicate the state they teach in and were listed as not reported.

The majority of the respondents were male (60.6\%) while 124 (39.4\%) were female. The largest group of respondents (22.6\%) indicated they had only been teaching for 1-5 years. The second largest group (20.7\%) had been teaching for more than 25 years. The smallest group consisted of 16 respondents (5.1\%) who indicated they had less than one year of teaching experience.

The respondents were asked their opinions on a number of factors that affect their views and the importance and the emphasis they place on SAEs in their agricultural education program. Composite score averages for each group was calculated for comparison. The composite score average for the values of SAEs questions $(M=3.27)$ indicated that the respondents "agreed" that there was value in students participating in SAEs.

Respondents agreed that SAEs provide good opportunities for students who participate in them $(\mathrm{M}=3.27)$. However, when asked about time issues associated with SAEs, the respondents had a slightly lower response $(M=2.96)$. This may indicate that the time issues associated with SAEs may have some effect on participation.

On average the respondents "agree" that they had a positive outlook on SAEs ( $M$ $=3.15$ ). Composite score averages were also calculated on a section of the survey regarding statements on SAE requirements. On average the respondents agreed with the statements on the requirements of SAEs $(M=2.80)$. 
When asked about recognition issues with SAEs, on average for this section $(M=$ 3.37) respondents "agreed" with the statements presented. The scores for this section indicate that respondents felt the recognition from SAEs was satisfactory and something to use to encourage students to participate.

Respondents "agreed" $(M=3.01)$ with a series of statements regarding teacher competence with SAEs. This indicated they felt competent in the material and felt they were teaching the material in a way to promote SAEs.

Respondents were presented with a series of statements associated with support of SAEs. On average respondents "agreed" with the statements $(M=2.72)$, meaning they feel students are getting the support needed for SAEs.

Respondents had a level of "agreement" $(M=2.74)$ with the statements regarding program issues associated with SAEs. Responses indicated that teachers felt program issues were playing a role in SAE participation.

\section{Conclusions}

Based on the results of this study, the following conclusions were made:

1. SAEs are a valuable component of agricultural education that promotes life-long learning,

2. Educators indicated that there is a substantial value in students participating in SAEs,

3. Agricultural education teachers indicated there were ample opportunities provided by SAEs to encourage students to participate,

4. Agricultural education teachers indicated that time issues associated with SAEs played a role in students not participating, 
5. Agricultural education teachers indicated positive thoughts and opinions regarding student outlook on SAEs,

6. Agricultural education teachers indicated that some SAE requirements may be too much for all students to be successful,

7. Agricultural education teachers indicated that students participating in SAEs receive ample recognition for their work,

8. Agricultural education teachers indicated they were competent in their abilities to teach SAEs,

9. Agricultural education teachers indicated that support from home plays a role in student participation in SAEs,

10. Respondents indicated that issues within the agricultural education program have an effect on SAE participation,

11. Record keeping involved with SAEs is valuable to students' futures,

12. Respondents incorporate students SAEs into grades to promote student participation,

13. There are ample opportunities for all students to participate in SAEs,

14. Students have the opportunity to use both farm and off-farm placement as an SAE,

15. Respondents indicated they have too many students in their program to supervise if everyone has an SAE,

16. Educators indicators that SAEs are worth the extra time required, due to the impact they have on the students, 
17. Educators are not being allotted release time from school to be used for SAE supervision,

18. Educators indicated that most parents view SAEs as a valuable learning tool for their children,

19. Although the numbers are small, educators have observed students who receive a FFA degree without having a SAE program,

20. Educators have also observed students elected to a State FFA office without having a SAE program,

21. The majority of the respondents indicated they had received training on how to supervise SAEs in their teacher preparation programs,

22. SAEs are regularly referred to during class room instruction,

23. Most agricultural education programs are receiving more recognition from their FFA program then they receive from SAE participation, and

24. A majority of educators focus more of their time on FFA activities then SAEs within their agricultural education program.

\section{Recommendations}

The researcher offers the following recommendations based on the results of the study.

1. Many issues with SAEs relate to problems with time. Agricultural education teachers have too many students, they are not allotted release time to supervise SAEs, and other activities hold precedence due to more recognition. Educators need to push for extended employment contracts and travel reimbursement to make SAE visitations more feasible. With this extra time educators will be more 
likely to make SAE visitations which will in turn promote and encourage students to participate.

2. Agricultural education teachers deal with students from many backgrounds, ruralfarm, non-farm, suburban, etc. Many agricultural education students do not feel they have the skills, background or equipment to participate in traditional SAEs. Agricultural education teachers should work with these students to organize and setup nontraditional SAE opportunities. Promoting exploratory and research SAEs will give these students opportunities to participate in a program that otherwise they may have missed out on.

3. Agricultural educators have voiced concerns regarding time. They feel they do not have time to make SAE visitations to all students, so often they do not. SAE home visits may be one of the most important keys to a successful agricultural education program. Visits allow a teacher to gain an idea of students' background and home life. SAE visits create a relationship with students and their parents that other educators do not have. SAE visitations are crucial to program success, whether a teacher is on an extended contract or not he/she must make time for visits.

4. Many issues and concerns voiced by agricultural educators deal with time, numbers and lack of recognition for SAEs. For these reasons educators are not putting the emphasis on SAEs. Recognition is a driving force for youth, when looking at different aspects of agricultural education it is clear that most recognition lies with the FFA organization. If states would provide more recognition to those individuals and programs excelling with SAEs a domino 
effect would be felt. As students see more SAEs put in the spotlight they will be encouraged and pushed to participate and apply for proficiency awards.

Proficiency awards can lead to monetary awards and scholarships providing students with the opportunity to better themselves and their program. As students succeed the program will grow and gain more exposure. Agricultural educators should use this exposure to help pursue extended contracts. Extended contracts will allow more time to make sure all students are being provided ample opportunities to work with the instructor to improve his/her SAE.

5. Although only a small number of educators indicated they had observed students receive FFA degrees or be elected to a State office without an SAE this is something that must addressed. Agricultural educators have chosen to put themselves in a position to work with youth and have a large impact on their life. Agricultural educators have chosen this profession and need to act as professionals. No student can earn recognition from SAEs without an educators support and consent. It is crucial to the integrity of the agricultural education program that educators allow only those students who have legitimately earned the right to be recognized receive recognition. 


\section{REFERENCES}

Ary, D., Jacobs, L. C., Razavieh, A., \& Sorensen, C. (2006). Introduction to research in education. Belmont: Thomson Wadsworth.

Boone, H. N., Doefert, D. L., \& Elliot, J. (1987). Supervised occupational experience programs:History, philosophy, current status and future implications. Jounal of the Association of Teacher Educators in Agriculture, 28(4), 57-64.

Camp, W. G., Clarke, A., \& Fallon, M. (2000). Revisiting supervised agricultural experience. Journal of Agricultural Education, 41(3), 13-22.

Cheeck, J. G., Arrington, L. R., Carter, S., \& Randell, R. S. (1994). Relationship of supervised agricultural expereience program participation and student achievement in agricultural education. Journal of Agricultural Education, 34(2), $1-5$.

Dillman, D. (2000). Mail and internet surveys, the tailored design method (2 $2^{\text {nd }}$ ed.). New York: John Wiley \& Sons.

Dyer, J. E., \& Osborne, E. (1996). Developing a model for supervised agricultural experience program quality: A synthesis of research. Journal of Agricultural Education, 37(2), 24-30.

Dyer, J. E., \& Osbourne, E. W. (1995). Participation in supervised agricultural experience programs: A synthesis of research. Journal of Agricultural Education, 36(1) , 614.

Dyer, J. E., \& Williams, D. L. (1997). Benefits of supervised agricultural expereince programs: A synthesis of research. Journal of Agricultural Education, 38(4), 5058.

Dyer, J. E., \& Williams, D. L. (1997). Supervision of supervised agricultural experience programs:A synthesis of research. Journal of Agricultural Education, 38(4), 59.

Harris, D., \& Newcomb, L. (1985). Vocational agriculture teacher characteristics and their relationship to perceptions of SOE importance, attitudes toward supervision, and quality of supervised occupational experience program. The Journal of the American Association of Teacher Educators in Agriculture , 26, 31-39.

Herren, R., H., \& Cole, L. (1984). Attitudes of Oregon vocational agriculture teachers toward the supervised occupational experience program component of the vocational agriculture curriculum. Journal of the American Assocation of Teacher Educators in Agriculture. , 45-51.

Lamberth, E. (1986). Determining perceptions of vocational agriculture teachers toward supervised occupational experience programs in Tennessee. Tennessee Technological University, College of Agriculture and Home Economics. 
Leising, J., \& Zilbert, E. (1985). Factors associated with supervised occupational experience in California vocational agriculture programs. The Journal of the American Association of Teacher Educators in Agriculture, 26, 56-64.

McCall, D. (1983). Status of supervised occupational experience in Colorado vocational agriculture programs. Dissertation Abstracts International .

National FFA Organization. (2009). Official FFA manual. Indianapolis: National FFA Organization.

National FFA Organization. (n.d.). Agricultural education. Retrieved November 18, 2009, from National FFA organization: http://www.ffa.org/

Pals, D. A. (1988). The value of supervised occupational experience programs as perceived by students. Journal of Agricultural Education, 29( 2), 32-39.

Pals, D. A. (1989). Value of supervised occupational experience programs as perceived by parents, employers, and vocational agriculture instructors. Journal of Agricultural Education, 30(2 ), 18-25.

Penrod, K. (1985). Supervised occupational experience assessed in terms of a theory of education. Dissertation Abstracts International .

Phipps, L., \& Osborne, E. (1988). Handbook on agricultural education in public schools. Danville, IL: The Interstate Printers \& Publishers, Inc.

Phipps, Osbourne, Dyer, \& Ball. (2008). Handbook on Agricultural Education in Public Schools, Sixth Edition. NY: Thomson Delmar Learning.

Rawls, H. (1980). Parental perceptions of the benefits vocational agriculture studetns derive from supervised occupational experience. The Journal of Association of Teacher Educators in Agriculture, 21(3), 14-17.

Rawls, W. (1982). An analysis of benefits derived from supervised occupational experience programs. The Journal of Association of Teacher Educators in Agriculture, 23(1), 31-38.

Robinson J. P., Shaver P. R., \& Wrightsman L. S. (1991). Criteria for scale selection and evalution. New York: Academic Press.

Shelhamer, V. (1984). Effectiveness of SOE in Montana's vocational agriculture program. Montana State University, Department of Agricultural and Inducstrial Education. 
APPENDICES 
APPENDIX A

Cover Letter E-mail Correspondence 
Dear Agricultural Education Teachers:

As a current teacher you know the time and effort that is required to develop and maintain a good agricultural education program. You have an appreciation and understating of the three integral components of an agricultural education, classroom/lab, FFA and SAE. As an active teacher you have a unique perspective into these different aspects of agricultural education. We are interested in your views on the emphasis and importance of supervised agricultural experiences in agricultural education.

I am John Workman, a graduate student in Agricultural and Extension Education at West Virginia University. Under the director of my advisor, Dr. Harry N. Boone, I am conducting a research study to determine the importance and emphasis agricultural education teachers are putting on supervised agricultural experience programs. The results of this study will be used to prepare a thesis to partially fulfill the requirements for a Master of Science degree in Agricultural and Extension Education. The results will provide insight to agricultural education teachers, universities, and state supervisors involved with the SAE experience.

Participation in this research study is voluntary, and will take approximately ten minutes of time. You may skip any question you are not comfortable answering or may quit at any point and submit the partially completed questionnaire. All responses will be held as confidential as possible. Survey results will be reported in a summary format and individual responses will not be identifiable. Please answer all questions honestly. There is no penalty and services will not be withheld if you choose not to participate.

The online survey can be assesses through the following site: http://www.zoomerang.com/Survey/WEB22AE99NHGS4. This link will direct you to the online questionnaire. After completing the survey click on the submit button. West Virginia University's IRB acknowledgement of this research is on file.

We thank you in advance for your participation in the study. Please submit the completed survey by Friday April 30, 2010. If you have questions please contact John at 304-293-5661 or Dr. Harry Boone at 304-293-5451.

Sincerely,

John A. Workman

Graduate Student
Harry N. Boone, Jr., Ph.D. AGEE Department Chair 
APPENDIX B

Online Survey 


\title{
The Emphasis and Importance Agricultural Education Teachers Place on Supervised Agricultural Experience Programs.
}

If you have questions about the questionnaire please contact:

\author{
John A. Workman \\ Graduate Student \\ Agricultural and Extension Education \\ jworkma9@mix.wvu.edu
}

(304) 293-5661

\section{The Value of Students Participating in SAEs}

Instructions: Using the following Likert scale, indicate your level of agreement with each of the following statements. Indicate your opinion by clicking on the button that best corre spond to your response: 1 Strongly Agree, 2 - Agree, 3 - Disagree, or 4 - Strongly Disagree.

1 SAE's are a valuable component of agricultural education.

\begin{tabular}{cccc}
\hline St ongly Agree & Agree & Dis agree & Stronghy dis agree \\
\hline 1 & 2 & 3 & 4 \\
\hline
\end{tabular}

2 SAE's are a valuable learning experience for students in agricultural education.

\begin{tabular}{cccc}
\hline Stronghy Agree & Agree & Disagree & Stronghy Dis agree \\
\hline 1 & 2 & 3 & 4 \\
\hline
\end{tabular}


3 Participation in SAEs improves students' attitudes toward non-school related work.

\begin{tabular}{cccc}
\hline Stronghy Agree & Agree & Disagree & Stronghy Disagree \\
\hline 1 & 2 & 3 & 4 \\
\hline
\end{tabular}

4 SAEs are a valuable way to promote experiential (hands on) learning.

\begin{tabular}{cccc}
\hline Stronghy Agree & Agree & Disagree & Stronghy Disagree \\
\hline 1 & 2 & 3 & 4 \\
\hline
\end{tabular}

\section{The Emphasis and Importance} Agricultural Education Teachers Place on Supervised Agricultural Experience Programs.

5 SAE record keeping is valuable to the students' future.

\begin{tabular}{cccc}
\hline Strongly Agree & Agree & Dis agree & Strongly Dis agree \\
\hline 1 & 2 & 3 & 4 \\
\hline
\end{tabular}

6 SAEs are an educational tool that provides life-long learning

\begin{tabular}{cccc}
\hline Stronghy Agree & Agree & Disagree & Stronghy Dis agree \\
\hline 1 & 2 & 3 & 4 \\
\hline
\end{tabular}

7 Grades should be used to encourage student SAEs. 


\begin{tabular}{cccc}
\hline Strongly Agree & Agree & Dis agree & Stronghy Dis agree \\
\hline 1 & 2 & 3 & 4 \\
\hline
\end{tabular}

8 As an agriculture teacher I incorporate SAEs into my student grades.

\begin{tabular}{cccc}
\hline Strongly Agree & Agree & Disagree & Stronghy Disagree \\
\hline 1 & 2 & 3 & 4 \\
\hline
\end{tabular}

9 SAEs help to develop competencies in agriculture.

\begin{tabular}{cccc}
\hline St onghy Agree & Agree & Dis agree & Stronghy Dis agree \\
\hline 1 & 2 & 3 & 4 \\
\hline
\end{tabular}

10 Students should earn graduation credits for their SAEs.

\begin{tabular}{cccc}
\hline Strongly Agree & Agree & Dis agree & Strongly Disagree \\
\hline 1 & 2 & 3 & 4 \\
\hline
\end{tabular}

11 My students receive academic credit (cre dit toward graduation) each year for successfully completing an approved supervised experience program.

\begin{tabular}{cccc}
\hline Strongly Agree & Agree & Disagree & Strongly Dis agree \\
\hline 1 & 2 & 3 & 4 \\
\hline
\end{tabular}

12 The only successful SAEs are those in which the student makes a monetary profit.

\begin{tabular}{cccc}
\hline Stronghy Agree & Agree & Disagree & Strongly Disagree \\
\hline 1 & 2 & 3 & 4 \\
\hline
\end{tabular}

13 SAEs increase student interest in agriculture. 


\begin{tabular}{cccc} 
St ongly Agree & Agree & Dis agree & Stronghy Dis agree \\
\hline 1 & 2 & 3 & 4 \\
\hline
\end{tabular}

\section{The Emphasis and Importance Agricultural Education Teachers Place on Supervised Agricultural Experience Programs.}

\section{Opportunities Provided by SAEs}

Instructions: Using the following Likert scale, indicate your level of agreement with each of the following statements. Indicate your opinion by clicking on the button that best correspond to your response: 1 Strongly Agree, 2 - Agree, 3 - Disagree, or 4 - Strongly Dis agree.

14 SAEs give agricultural education students opportunities that other students do not receive.

\begin{tabular}{cccc}
\hline Strongly Agree & Agree & Disagree & Stronghy D is agree \\
\hline 1 & 2 & 3 & 4 \\
\hline
\end{tabular}

$15 \mathrm{SAE}$ opportunities are available to all students in my program.

\begin{tabular}{cccc}
\hline Strongly Agree & Agree & Disagree & Stronghy Disagree \\
\hline 1 & 2 & 3 & 4 \\
\hline
\end{tabular}

16 I teach all students in my program about SAEs.

Strongly Agree Agree Dis agree Strongly Dis agree




$\begin{array}{llll}1 & 2 & 3 & 4\end{array}$

17 Students in my program have the opportunity to use offfarm placement as a $\mathrm{SAE}$.

\begin{tabular}{cccc}
\hline Stronghy Agree & Agree & Disagree & Stronghy Dis agree \\
\hline 1 & 2 & 3 & 4 \\
\hline
\end{tabular}

18 Students in my program have the opportunity to use farm placement as a SAE.

\begin{tabular}{cccc}
\hline Strongly Agree & Agree & Disagree & Strongly Dis agree \\
\hline 1 & 2 & 3 & 4 \\
\hline
\end{tabular}

19 Opportunities for SAEs are limited in my community.

\begin{tabular}{cccc}
\hline Strongly Agree & Agree & Dis agree & Strongly Dis agree \\
\hline 1 & 2 & 3 & 4 \\
\hline
\end{tabular}

20 A SAE should help prepare students for their career occupational goal.

\begin{tabular}{cccc}
\hline Stronghy Agree & Agree & Disagree & Stronghy Dis agree \\
\hline 1 & 2 & 3 & 4 \\
\hline
\end{tabular}

The Emphasis and Importance Agricultural Education Teachers Place on Supervised Agricultural Experience Programs. 


\section{Time and SAEs}

Instructions: Using the following Likert scale, indicate your level of agre ement with each of the following statements. Indicate your opinion by clicking on the button that best correspond to your response: 1 Strongly Agree, 2 - Agree, 3 - Disagree, or 4 - Strongly Disagree.

21 I hold meetings with parents/guardians to explain the purpose, values, and types of SAEs.

\begin{tabular}{cccc}
\hline Stronghy Agree & Agree & Disagree & Stronghy D is agree \\
\hline 1 & 2 & 3 & 4 \\
\hline
\end{tabular}

22 I conduct visits to prospective students to explain the purpose, values, and types of SAEs.

\begin{tabular}{cccc}
\hline Strongty Agree & Agree & Disagree & Stronghy Dis agree \\
\hline 1 & 2 & 3 & 4 \\
\hline
\end{tabular}

23 Agriculture teachers are responsible for supervision of students' SAE programs.

\begin{tabular}{cccc}
\hline Stronghy Agree & Agree & Disagree & Stronghy Dis agree \\
\hline 1 & 2 & 3 & 4 \\
\hline
\end{tabular}

$24 \mathrm{SAE}$ records are kept on a calendar year basis.

\begin{tabular}{cccc}
\hline St ongly Agree & Agree & Dis agree & Strongly Dis agree \\
\hline 1 & 2 & 3 & 4 \\
\hline
\end{tabular}

25 There are too many students in my program to supervise everyone that has a SAE. 


\begin{tabular}{cccc} 
Stronghy Agree & Agree & Disagree & Stronghy Disagree \\
\hline 1 & 2 & 3 & 4 \\
\hline
\end{tabular}

26 I spend time in the classroom teaching SAE record keeping.

\begin{tabular}{cccc}
\hline Strongly Agree & Agree & Disagree & Stronghy Dis agree \\
\hline 1 & 2 & 3 & 4 \\
\hline
\end{tabular}

27 I use class time to supervise $\mathrm{SAE}$ record keeping.

\begin{tabular}{cccc}
\hline Strongly Agree & Agree & Dis agree & Strongly Dis agree \\
\hline 1 & 2 & 3 & 4 \\
\hline
\end{tabular}

28 I am willing to take extra time to make sure students' SAEs are being properly supervised.

\begin{tabular}{cccc}
\hline Stronghy Agree & Agree & Disagree & Stronghy Dis agree \\
\hline 1 & 2 & 3 & 4 \\
\hline
\end{tabular}

29 I keep SAE visitation records for my program.

\begin{tabular}{cccc}
\hline Strongly Agree & Agree & Dis agree & Stronghy Dis agree \\
\hline 1 & 2 & 3 & 4 \\
\hline
\end{tabular}

The Emphasis and Importance Agricultural Education Teachers Place on Supervised Agricultural Experience Programs. 


\section{Time and SAEs}

Instructions: Using the following Likert scale, indicate your level of agreement with each of the following statements. Indicate your opinion by clicking on the button that best correspond to your response: 1 Strongly Agree, 2 - Agree, 3 - Disagree, or 4 - Strongly Disagree.

30 I spend extra time teaching SAE concepts to freshman.

\begin{tabular}{cccc}
\hline St ongly Agree & Agree & Dis agree & Strongly Dis agree \\
\hline 1 & 2 & 3 & 4 \\
\hline
\end{tabular}

31 SAEs are worth the extra effort required of the agricultural educator.

\begin{tabular}{cccc}
\hline Strongly Agree & Agree & Disagree & Stronghy Disagree \\
\hline 1 & 2 & 3 & 4 \\
\hline
\end{tabular}

32 During the school year I am allotted release time from school to supervise students SAEs.

\begin{tabular}{cccc}
\hline Strongly Agree & Agree & Disagree & Stronghy Dis agree \\
\hline 1 & 2 & 3 & 4 \\
\hline
\end{tabular}

33 I am employed during the summer which allows for SAE supervision.

\begin{tabular}{cccc}
\hline Stronghy Agree & Agree & Disagree & Stronghy Disagree \\
\hline 1 & 2 & 3 & 4 \\
\hline
\end{tabular}

SUBMIT 


\section{The Emphasis and Importance Agricultural Education Teachers Place on Supervised Agricultural Experience Programs.}

\section{Thoughts on SAEs}

Instructions: Using the following Likert scale, indicate your level of agreement with each of the following statements. Indicate your opinion by clicking on the button that best corre spond to your response: 1 Strongly Agree, 2 - Agree, 3 - Disagree, or 4 - Strongly Dis agree.

34 I have a solid understanding of the characteristics of an acceptable SAE.

\begin{tabular}{cccc}
\hline Strongly Agree & Agree & DE agree & Stronghy Disagree \\
\hline 1 & 2 & 3 & 4 \\
\hline
\end{tabular}

35 SAEs should not be considered one of three essential components of the agricultural education program.

\begin{tabular}{cccc}
\hline Strongly Agree & Agree & Disagree & Stronghy Disagree \\
\hline 1 & 2 & 3 & 4 \\
\hline
\end{tabular}

36 I visit every student at least once each year to supervise his/her SAE program.

\begin{tabular}{cccc}
\hline Strongly Agree & Agree & Disagree & Stronghy Dis agree \\
\hline 1 & 2 & 3 & 4 \\
\hline
\end{tabular}

37 I provide real life examples of SAEs to students in my program.

Stronghy Agree Agree Disagree Stronghy Disagree




$12 \quad 2 \quad 3 \quad 4$

38 I take an active role in helping students design a SAE program.

\begin{tabular}{cccc}
\hline Stronghy Agree & Agree & Disagree & Stronghy Disagree \\
\hline 1 & 2 & 3 & 4 \\
\hline
\end{tabular}

39 Record keeping is a crucial part of a student SAE program.

\begin{tabular}{cccc}
\hline Stronghy Agree & Agree & Disagree & Stronghy Dis agree \\
\hline 1 & 2 & 3 & 4 \\
\hline
\end{tabular}

40 Record keeping plays too large of a role in SAEs.

\begin{tabular}{cccc}
\hline Strongly Agree & Agree & Dis agree & Strongly Dis agree \\
\hline 1 & 2 & 3 & 4 \\
\hline
\end{tabular}

41 A SAE program should show growth and expansion over the student's career in the agriculture program.

\begin{tabular}{cccc}
\hline Stronghy Agree & Agree & Disagree & Stronghy Disagree \\
\hline 1 & 2 & 3 & 4 \\
\hline
\end{tabular}

42 One state has a standard that a desired SAE program is one in which a student will have earned and productively invested at least $\$ 1,000$, or worked at le ast 300 hours in excess of scheduled class time, or a combination thereof, in a supervised agricultural experience program at the completion of four years.

\section{Do you agr ee with this standard?}

\begin{tabular}{cccc}
\hline Stronghy Agree & Agree & Disagree & Stronghy Dis agree \\
\hline 1 & 2 & 3 & 4 \\
\hline
\end{tabular}




\section{The Emphasis and Importance Agricultural Education Teachers Place on Supervised Agricultural Experience Programs.}

\section{Requirements for SAEs}

Instructions: Using the following Likert scale, indicate your level of agreement with each of the following statements. Indicate your opinion by clicking on the button that best corre spond to your response: 1 Strongly Agree, 2 - Agree, 3 - Disagree, or 4 - Strongly Disagree.

43 I make sure that all students enrolled in agricultural education have a SAE.

\begin{tabular}{cccc}
\hline Stronghy Agree & Agree & Disagree & Strongly Disagree \\
\hline 1 & 2 & 3 & 4 \\
\hline
\end{tabular}

44 All agricultural education students are required to complete an SAE.

\begin{tabular}{cccc}
\hline Stronghy Agree & Agree & Disagree & Stronghy Dis agree \\
\hline 1 & 2 & 3 & 4 \\
\hline
\end{tabular}

45 All students with a SAE are keeping a record book.

\begin{tabular}{cccc}
\hline Strongly Agree & Agree & Dis agree & Strongly Dis agree \\
\hline 1 & 2 & 3 & 4 \\
\hline
\end{tabular}


46 There are too many students in my program to require SAEs.

\begin{tabular}{cccc}
\hline Stronghy Agree & Agree & Disagree & Stronghy Dis agree \\
\hline 1 & 2 & 3 & 4 \\
\hline
\end{tabular}

47 All of my 'ownership/entrepreneurial' students have approved business agreements.

\begin{tabular}{cccc}
\hline Stronghy Agree & Agree & Disagree & Stronghy Dis agree \\
\hline 1 & 2 & 3 & 4 \\
\hline
\end{tabular}

48 All of my 'placement' students have a training agreement.

\begin{tabular}{cccc}
\hline Strongly Agree & Agree & Dis agree & Strongly Dis agree \\
\hline 1 & 2 & 3 & 4 \\
\hline
\end{tabular}

49 Students submit a portfolio to the programs agricultural education teacher to document completion of their SAE.

\begin{tabular}{cccc}
\hline Strongly Agree & Agree & Disagree & Stronghy Disagree \\
\hline 1 & 2 & 3 & 4 \\
\hline
\end{tabular}

\section{The Emphasis and Importance Agricultural Education Teachers Place on Supervised Agricultural Experience Programs.}




\section{Recognition and SAEs}

Instructions: Using the following Likert scale, indicate your level of agre ement with each of the following statements. Indicate your opinion by clicking on the button that best correspond to your response: 1 Strongly Agree, 2 - Agree, 3 -Disagree, or 4 - Strongly Disagree.

50 Students are encouraged to participate in SAEs because of the potential recognition a student can earn.

\begin{tabular}{cccc}
\hline Stronghy Agree & Agree & Disagree & Stronghy Dis agree \\
\hline 1 & 2 & 3 & 4 \\
\hline
\end{tabular}

51 Students must maintain a SAE program to obtain the Chapter FFA degree.

\begin{tabular}{cccc}
\hline Stronghy Agree & Agree & Disagree & Stronghy Dis agree \\
\hline 1 & 2 & 3 & 4 \\
\hline
\end{tabular}

52 Students must maintain a SAE program to obtain the State FFA degree.

\begin{tabular}{cccc}
\hline Stronghy Agree & Agree & Disagree & Stronghy Dis agree \\
\hline 1 & 2 & 3 & 4 \\
\hline
\end{tabular}

53 Students must maintain a SAE program to obtain the American FFA degree.

\begin{tabular}{cccc}
\hline Stronghy Agree & Agree & Disagree & Stronghy Dis agree \\
\hline 1 & 2 & 3 & 4 \\
\hline
\end{tabular}

54 Students must maintain a SAE program to be elected to and hold a state FFA office.

Stronghy Agree Agree Disagree Stronghy Disagree


55 Students should be required to maintain a $\mathrm{SAE}$ program to obtain the Chapter FFA degree.

\begin{tabular}{cccc}
\hline Strongly Agree & Agree & Disagree & Stronghy Dis agree \\
\hline 1 & 2 & 3 & 4 \\
\hline
\end{tabular}

56 Students should be required to maintain a $\mathrm{SAE}$ program to obtain the State FFA degree.

\begin{tabular}{cccc}
\hline Strongly Agree & Agree & Disagree & Stronghy Dis agree \\
\hline 1 & 2 & 3 & 4 \\
\hline
\end{tabular}

57 Students should be required to maintain a $\mathrm{SAE}$ program to obtain the American FFA degree.

\begin{tabular}{cccc}
\hline Strongly Agree & Agree & Disagree & Strongly Dis agree \\
\hline 1 & 2 & 3 & 4 \\
\hline
\end{tabular}

58 Students should be required to maintain a SAE program to be elected to and hold a state FFA office.

\begin{tabular}{cccc}
\hline Strongly Agree & Agree & Dis agree & Strongly Dis agree \\
\hline 1 & 2 & 3 & 4 \\
\hline
\end{tabular}

59 I have observed student(s) receive a FFA degree (Chapter, State, American) without having a SAE program.

\begin{tabular}{cccc}
\hline Strongly Agree & Agree & Disagree & Stronghy Disagree \\
\hline 1 & 2 & 3 & 4 \\
\hline
\end{tabular}

60 I have observed student(s) elected to a State FFA office without having a $\mathrm{SAE}$ program. 


\begin{tabular}{cccc} 
Stronghy Agree & Agree & Disagree & Stronghy Dis agree \\
\hline 1 & 2 & 3 & 4 \\
\hline
\end{tabular}

\section{The Emphasis and Importance Agricultural Education Teachers Place on Supervised Agricultural Experience Programs.}

\section{Instructor Competence with SAEs}

Instructions: Using the following Likert scale, indicate your level of agreement with each of the following statements. Indicate your opinion by clicking on the button that best correspond to your response: 1 Strongly Agree, 2 - Agree, 3 - Disagree, or 4 - Strongly Dis agree.

61 I am not familiar enough with concepts of SAEs to feel comfortable teaching the topic.

\begin{tabular}{cccc}
\hline Strongly Agree & Agree & Disagree & Stronghy Disagree \\
\hline 1 & 2 & 3 & 4 \\
\hline
\end{tabular}

62 I am not familiar enough with $\mathrm{SAE}$ record keeping to feel comfortable teaching record keeping practices.

\begin{tabular}{cccc}
\hline Strongly Agree & Agree & Disagree & Stronghy Disagree \\
\hline 1 & 2 & 3 & 4 \\
\hline
\end{tabular}

63 I did not receive training on how to supervise SAEs in my teacher preparation program. (classes, workshops, etc.) 


\begin{tabular}{cccc}
\hline Stronghy Agree & Agree & Disagree & Stronghy Dis agree \\
\hline 1 & 2 & 3 & 4 \\
\hline
\end{tabular}

64 I am not familiar with newer types of SAEs such as the research $\mathrm{SAE}$.

\begin{tabular}{cccc}
\hline Stronghy Agree & Agree & Disagree & Stronghy Disagree \\
\hline 1 & 2 & 3 & 4 \\
\hline
\end{tabular}

65 I am not familiar with newer types of SAEs such as the exploratory SAE.

\begin{tabular}{cccc}
\hline Strongly Agree & Agree & Disagree & Stronghy Dis agree \\
\hline 1 & 2 & 3 & 4 \\
\hline
\end{tabular}

66 I have an adequate understanding of SAEs.

\begin{tabular}{cccc}
\hline St ongly Agree & Agree & Dis agree & Stronghy Dis agree \\
\hline 1 & 2 & 3 & 4 \\
\hline
\end{tabular}

67 I regularly refer to SAEs during class period instruction.

\begin{tabular}{cccc}
\hline Strongly Agree & Agree & Dis agree & Stronghy Dis agree \\
\hline 1 & 2 & 3 & 4 \\
\hline
\end{tabular}

SUBMIT

Survey Page 9

The Emphasis and Importance Agricultural Education Teachers Place on Supervised Agricultural Experience Programs. 


\section{Support with SAEs}

Instructions: Using the following Likert scale, indicate your level of agre ement with each of the following statements. Indicate your opinion by clicking on the button that best correspond to your response: 1 Strongly Agree, 2 - Agree, 3 -Disagree, or 4 - Strongly Disagree.

68 I am reimbursed for travel to complete SAE visitations.

\begin{tabular}{cccc}
\hline Strongly Agree & Agree & Dis agree & Strongly Dis agree \\
\hline 1 & 2 & 3 & 4
\end{tabular}

69 I keep a list of employers who are willing to serve as a training center for students' SAEs.

\begin{tabular}{cccc}
\hline Stronghy Agree & Agree & Disagree & Stronghy D is agree \\
\hline 1 & 2 & 3 & 4 \\
\hline
\end{tabular}

70 I work with my advi sory committee to develop a list of prospective training center employers for placement SAEs.

\begin{tabular}{cccc}
\hline Strongly Agree & Agree & Disagree & Stronghy Disagree \\
\hline 1 & 2 & 3 & 4 \\
\hline
\end{tabular}

71 I work with my administration to develop a list of prospective training center employers for pl acement SAEs.

\begin{tabular}{cccc}
\hline Stronghy Agree & Agree & Disagree & Stronghy Disagree \\
\hline 1 & 2 & 3 & 4 \\
\hline
\end{tabular}

72 I interview prospective cooperating employers to 
determine if the employment situation is suitable and the employer is interested in establishing a training center for $\mathrm{SAE}$ placement.

\begin{tabular}{cccc}
\hline Stronghy Agree & Agree & Disagree & Stronghy Disagree \\
\hline 1 & 2 & 3 & 4 \\
\hline
\end{tabular}

73 SAEs are an educational tool that leads to life-long learning.

\begin{tabular}{cccc}
\hline Strongly Agree & Agree & Disagree & Stronghy Disagree \\
\hline 1 & 2 & 3 & 4 \\
\hline
\end{tabular}

74 Most students lack the resources to have an adequate SAE.

\begin{tabular}{cccc}
\hline Strongly Agree & Agree & Dis agree & Stronghy Dis agree \\
\hline 1 & 2 & 3 & 4 \\
\hline
\end{tabular}

75 Most parents do not feel that SAEs are a valuable learning tool.

\begin{tabular}{cccc}
\hline Stronghy Agree & Agree & Disagree & Stronghy Dis agree \\
\hline 1 & 2 & 3 & 4 \\
\hline
\end{tabular}

76 SAEs provide students with adequate earnings for the amount of work required.

\begin{tabular}{cccc}
\hline Strongly Agree & Agree & Dis agree & Stronghy Dis agree \\
\hline 1 & 2 & 3 & 4 \\
\hline
\end{tabular}

77 My students have a good understanding of SAEs concepts.

\begin{tabular}{lll}
\hline Strongly Agree & Agree & Dis agree
\end{tabular}




\section{The Emphasis and Importance Agricultural Education Teachers Place on Supervised Agricultural Experience Programs.}

\section{The Program and SAEs}

Instructions: Using the following Likert scale, indicate your level of agre ement with each of the following statements. Indicate your opinion by clicking on the button that best corre spond to your response: 1 Strongly Agree, 2 - Agree, 3 - Disagree, or 4 - Strongly Disagree.

78 The agricultural program benefits from the SAE component.

\begin{tabular}{cccc}
\hline Strongly Agree & Agree & Disagree & Stronghy Dis agree \\
\hline 1 & 2 & 3 & 4 \\
\hline
\end{tabular}

79 SAE, FFA, and classroom experiences must all work together for a quality agricultural education program.

\begin{tabular}{cccc}
\hline Strongly Agree & Agree & Disagree & Stronghy Dis agree \\
\hline 1 & 2 & 3 & 4 \\
\hline
\end{tabular}

80 My agricultural education program receives more recognition from $F F A$ activities than $\mathrm{SAE}$ programs.

\begin{tabular}{llll}
\hline Strongly Agree & Agree & Disagree & Stronghy Disagree \\
\hline
\end{tabular}


81 I focus more on FFA activities instead of SAEs within my program.

\begin{tabular}{cccc}
\hline Strongly Agree & Agree & Disagree & Stronghy Dis agree \\
\hline 1 & 2 & 3 & 4 \\
\hline
\end{tabular}

\section{The Emphasis and Importance Agricultural Education Teachers Place on Supervised Agricultural Experience Programs.}

\section{Program Numbers}

Please give appropriate responses to each of the following questions.

82 How many students are currently enrolled in your agriculture program for the 2009-2010 school year?

83 How many students in your program have an active $\mathrm{SAE}$ program for the 2009-2010 school year?

84 How many students in your program earned the Chapter FFA degree during the 2009-2010 school year? 
85 How many students in your program applied for the State FFA degree during the 2009-2010 school year?

86 How many students in your program applied for the American FFA degree during the 2009-2010 school year?

87 How many students in your program applied for a state proficiency award during the 2009-2010 school year?

88 Please indicate the number of your 2009-2010 students with the following categories of SAEs:

Exploratory

Research

Ownership/Entrepreneur

Placement

89 A desired SAE is one in which a student will have earned and productively invested at least $\$$ , or worked at least_hours in excess of scheduled class time, or a combination thereof, in a supervised agricultural experience program at the completion of four years.

Dollar Value

Hours

90 Approximately how many hours are devoted to teaching SAEs in your programs introductory course?

91 Approximately how many hours are devoted to teaching 
SAEs in all other program courses? (per class)

\section{The Emphasis and Importance Agricultural Education Teachers Place on Supervised Agricultural Experience Programs.}

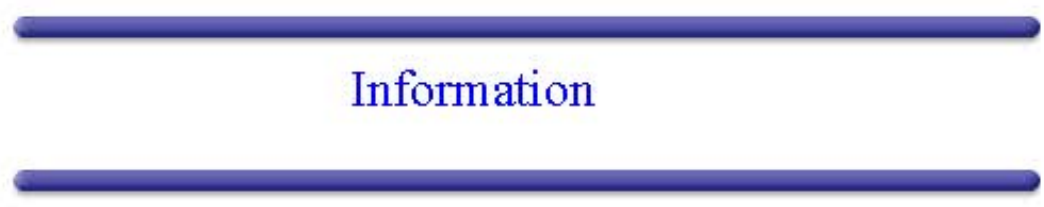

Please complete the following questions.

92 My school district would be described as:
- Rural- Farm
- Rural- Non-farm
- Suburban
Urban

93 I would describe the area that I grew up as:
- Rural- Farm
- Rural- Non-farm
- Suburban
- Urban

94 What is your gender?
- Male
- Female 
95 What is your current age?
- 21-30 years
- 31-40 years
- 41-50 years
- 51-60 years
- 60 years and over

96 How many years of teaching experience do you have?

- Less than one year

- 1-5 years

- 6-10years

- 11-15 years

- 16-20 years

- 21-25 years

- More than 25 years

97 Please indicate your college degrees earned. (answer all that apply)
Bachelors
(please specify)
Masters (please
spedify)
Doctoral (please
specify)
Other
(please specify)

98 What state are you currently teaching in?

99 Please use the following section to offer comments on the research and/or research instrument. 
VITA

John A. Workman

May 2005

May 2009

August 2010

\section{Graduated Roane County High School}

Graduated Bachelor of Science in Agriculture Major in Agricultural and Extension Education West Virginia University

Graduated Master of Science in Agricultural and Extension Education West Virginia University 